Chapman University

Chapman University Digital Commons

ESI Working Papers

Economic Science Institute

$6-2020$

Religion in Economic History: A Survey

Sascha O. Becker

Jared Rubin

Ludger Woessmann

Follow this and additional works at: https://digitalcommons.chapman.edu/esi_working_papers

Part of the Econometrics Commons, Economic Theory Commons, History of Religions of Western Origin Commons, and the Other Economics Commons 
Religion in Economic History: A Survey

Comments

ESI Working Paper 20-22 


\title{
Religion in Economic History: A Survey*
}

\author{
Sascha O. Becker, Jared Rubin, and Ludger Woessmann ${ }^{\dagger}$
}

Prepared for the Handbook of Historical Economics, ed. by Alberto Bisin and Giovanni Federico

\begin{abstract}
This chapter surveys the recent social science literature on religion in economic history, covering both socioeconomic causes and consequences of religion. Following the rapidly growing literature, it focuses on the three main monotheisms-Judaism, Christianity, and Islam-and on the period up to WWII. Works on Judaism address Jewish occupational specialization, human capital, emancipation, and the causes and consequences of Jewish persecution. One set of papers on Christianity studies the role of the Catholic Church in European economic history since the medieval period. Taking advantage of newly digitized data and advanced econometric techniques, the voluminous literature on the Protestant Reformation studies its socioeconomic causes as well as its consequences for human capital, secularization, political change, technology diffusion, and social outcomes. Works on missionaries show that early access to Christian missions still has political, educational, and economic consequences in present-day Africa, Asia, and Latin America. Much of the economics of Islam focuses on the role that Islam and Islamic institutions played in political-economy outcomes and in the "long divergence" between the Middle East and Western Europe. Finally, cross-country analyses seek to understand the broader determinants of religious practice and its various effects across the world. We highlight three general insights that emerge from this literature. First, the monotheistic character of the Abrahamic religions facilitated a close historical interconnection of religion with political power and conflict. Second, human capital often played a leading role in the interconnection between religion and economic history. Third, many socioeconomic factors matter in the historical development of religions.
\end{abstract}

June 2020

\footnotetext{
${ }^{*}$ For constructive comments, inspiring discussions, and/or joint work over many years, we thank Ran Abramitzky, Jeanet Bentzen, Alberto Bisin, Jean-Paul Carvalho, Eric Chaney, Francesco Cinnirella, Giovanni Federico, Avner Greif, Erik Hornung, Larry Iannaccone, Sriya Iyer, Murat Iyigun, Saumitra Jha, Mark Koyama, Timur Kuran, Rachel McCleary, Felix Meier zu Selhausen, Alex Moradi, Markus Nagler, Luigi Pascali, Steve Pfaff, and Felipe Valencia. Participants at the October 2019 Handbook Conference at NYU and at Robert Barro and Rachel McCleary's course on The Political Economy of Religion at Harvard University gave insightful feedback. Woessmann gratefully acknowledges the hospitality of the Hoover Institution, Stanford University, while working on this paper.

† Becker: Monash University, University of Warwick; CAGE; CEPR, CESifo, IZA, and ROA; sascha.becker@monash.edu. Rubin: Chapman University; jrubin@chapman.edu. Woessmann: University of Munich and ifo Institute; CESifo, IZA, and CAGE; woessmann@ifo.de.
} 


\section{Contents}

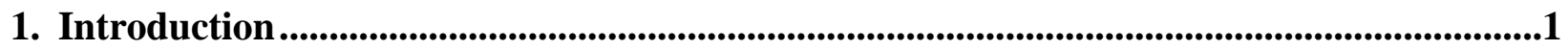

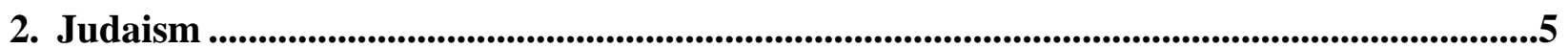

2.1 Jewish Occupational Specialization, Human Capital, and Emancipation ........................6

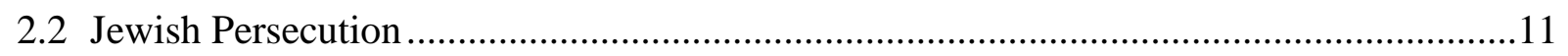

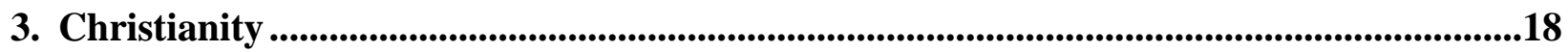

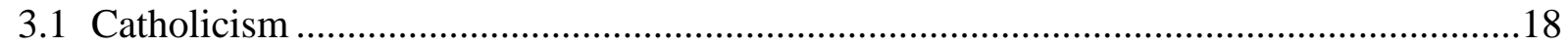

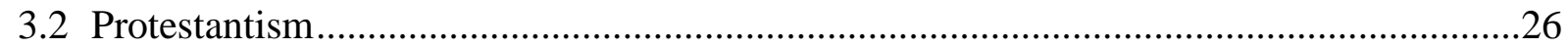

3.2.1 Socioeconomic Consequences of the Reformation ........................................... 26

3.2.2 Socioeconomic Causes of the Reformation, of its Spread, and of Protestant

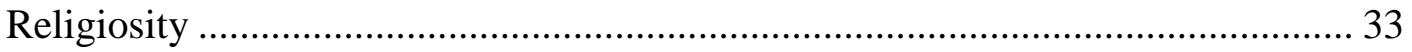

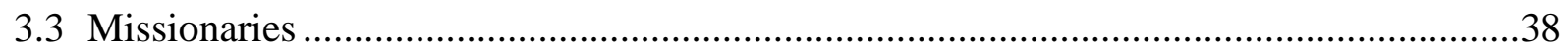

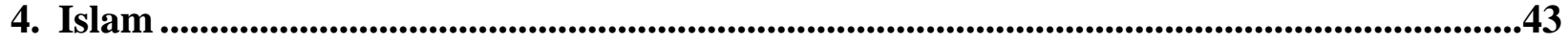

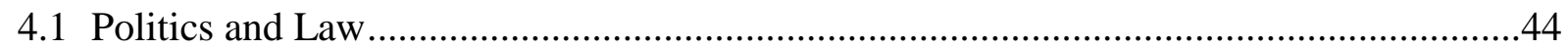

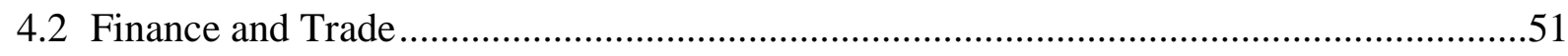

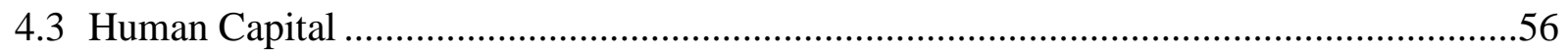

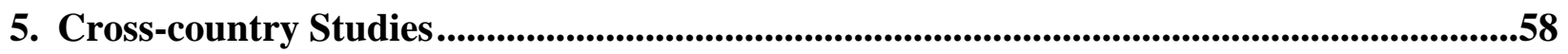

6. Conclusion................................................................................................................................61

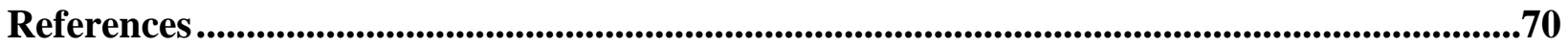




\section{Introduction}

Historically, religion has played an important role in Western societies, affecting or even defining individual beliefs and traits, cultural norms and values, social groups and organizations, and political and military power. A rapidly growing literature works to advance our understanding of the role of religion in economic history. How did religion and religious beliefs in God and the afterlife affect economic history? And how did historical socioeconomic circumstances shape religious beliefs and activities? In line with the recent revival of interest in the role of culture in economics more generally (e.g., Guiso, Sapienza, and Zingales 2006; Alesina and Giuliano 2015), study of the relevance of religion has entered center stage in the study of economic history.

The past two decades have seen the emergence of the study of "religion in economic history" as a new field. Although a subfield of both economic history and the economics of religion, the overlap between these two fields is a relatively recent development. Certainly, the economic study of religion has a long history itself, with a chapter of Adam Smith’s (1776) Inquiry into the Nature and Causes of the Wealth of Nations famously exploring the market for religion. But in Larry Iannaccone's 1998 survey on the economics of religion in the Journal of Economic Literature, only 18 of the 141 cited articles (12.8\%) could reasonably be construed to be historical, and many of those were directly related to Max Weber’s (1904/05) thesis of a Protestant ethic. At the turn of the millennium, the nascent economics of religion field was, if anything, much more closely related to the sociology of religion than economic history. This has changed in the last two decades. In this period, there has been enough work in the field to warrant two recent surveys on individual religions and economic history: Becker, Pfaff, and Rubin (2016) on the Protestant Reformation and Kuran (2018) on Islam (covering mostly historical, but also contemporary aspects). The broader economics of religion field has produced two handbooks in the last decade-McCleary 
(2011) and Carvalho, Iyer, and Rubin (2019) — both of which have numerous entries from economic history. The field is now sufficiently large that it warrants a survey that highlights unifying themes, overviews the big problems that the literature aims to address, and points to gaps that could be addressed by future research.

In line with the focus of the economics of religion in general, the study of religion in economic history covers two main areas of investigation. The first area is which (economic) factors cause religious adoption, religiosity, and religious change. The second area is which consequences religion exerts on economic development. While the new literature of the past two decades covers many different and sometimes disparate aspects within these two areas, we think that a few general insights have emerged that deserve highlighting.

First, the monotheistic character of the main Abrahamic religions facilitated a close historical interconnection of religion with political power and conflict. The doctrine that there is "one true God" that is the defining characteristic of monotheistic faiths was both a stabilizing factor for societies—-because monopolized rule could curtail disagreements within religious groups—and a destabilizing factor because it spurred conflict between religions (Iyigun 2015). Some of these aspects have been shown for Catholicism, where the institutionalized Church acted as a strong political player and religious doctrine influenced the development of communes, guilds, and lending markets. Similarly, different features of Islamic law affected conflict, finance, and many aspects of economic development in the Islamic world.

Second, human capital often played a leading role in the interconnection between religion and economic history. Religious norms spurred or prevented literacy and mass education in many societies. Religion-induced human capital has been a defining element both in Jewish economic 
history and in the Protestant-Catholic divide in Christian economic history, as well as in how Christian missionaries impacted the historical development in affected areas.

Third, it is possible to describe economic and wider factors that have facilitated the adoption and spread of religions and religious beliefs. While the specific causes studied in the literature are clearly diverse-ranging from practices of the incumbent religion and earthquake incidents to economic potential, trade routes, printing technology, competition, educational expansion, and personal ties-it is fair to conclude that the recent literature has produced ample evidence that socioeconomic factors matter in the historical development of religions.

We employ two criteria to define the coverage of our survey. We cover works that analyze one of the three main monotheisms—Judaism, Christianity, or Islam—and that primarily cover the period prior to 1945 . While both of these criteria are somewhat arbitrary, there is a rationale for each. In line with the particular role of monotheistic faiths outlined above, the vast majority of the work in this field has concerned one of the three Abrahamic religions. This is not to say there has not been good work done on Hinduism (especially the caste system), Buddhism, Shintoism, or animistic religions. Yet, there has not been nearly enough written on non-Abrahamic religions by quantitative economic historians to begin to categorize or search for running themes in the literature. We will return to this in the conclusion when we discuss potentially fruitful areas of future research. After all, Abrahamic religions only account for a little more than half of the world's population. We chose the end of World War II as an end date not because there is a fundamental divide at the point in time, but in large part because we needed to pick some point in time as a cut-off for a survey on economic history, and at minimum we thought it was appropriate to include the growing set of papers on the Holocaust. Moreover, Sriya Iyer (2016) has recently updated Iannaccone’s (1998) JEL survey, nicely covering many of the papers on religion in the 
latter half of the $20^{\text {th }}$ century. Extending our date too far would therefore create many redundancies. In any case, the pre-WWII literature on the economic history of the Abrahamic faiths is more than large enough to fill a survey, as the reader shall see below.

The research we highlight in this survey is largely from the last two decades; indeed, most of it is from the last decade. This is for two reasons. For one, the field has advanced immensely in the last two decades, and a majority of the social scientific work at the intersection of economics of religion and economic history is recent. Second, advancements in methodological and datagathering techniques have been so rapid that most empirical works of the last decade or so have a fundamentally different feel to them than their predecessors. For this reason, we largely focus on "large-N" studies. Historical case studies and smaller-scale studies are valuable—especially to derive broader hypotheses and to focus on local religious heterogeneity where it exists—but tend not to yield the type of causal claims or external validity that is possible with larger-scale studies. In covering topics of economic history (broadly defined), we also confine this survey (mostly) to work using an economics approach, i.e., applying economic concepts, methodology, and/or intuition. This includes some works of political science and sociology, but excludes many more that have limited economics focus. Of course, many of the covered topics-in particular, noneconomic topics such as anti-Semitism or the sources of religious feelings-inevitably are much more complex than the literature on the economics of religion can cover. The contribution by economics offers a complementary perspective to the richer coverage of these topics by historians, theologists, ethnographers, and other disciplines. In fact, multidisciplinary approaches may prove particularly fruitful in furthering our understating of the role of religion in economic history in the future. Finally, the papers we review are somewhat idiosyncratic and reflect our own biases 
(conscious and unconscious). This is probably unavoidable, but we do our best to bring together papers that fit into general themes that have arisen in the literature.

We organize this survey by religion, in order of the religion's age: Judaism, then Christianity, then Islam. Work on Judaism mostly covers two themes: first, Jewish occupational specialization, human capital, and emancipation (section 2.1); second, Jewish persecution (section 2.2). We subdivide the coverage of Christianity in three sections. First, work on Catholicism has a strong focus on the role of the Catholic Church in historical development (section 3.1). Second, recent studies of Protestantism cover both the socioeconomic consequences of the Reformation and the socioeconomic causes of its spread (section 3.2). Third, while the work on Catholicism and Protestantism per se mostly focuses on European history, recent work also studies how Christian missionaries affected historical development in sub-Saharan Africa, Asia, and Latin America (section 3.3). We structure the work on Islam into three themes: politics and law (section 4.1); finance and trade (section 4.2); and human capital (section 4.3). We close our survey with a section on cross-country studies that investigate economic causes and consequences of religion (section 5). The final section concludes with ideas for directions in which future research in the area might tread.

\section{Judaism}

Judaism is the oldest of the three Abrahamic religions and our natural starting point. Study of the economic history of Jews has a long pedigree in the social sciences. Salient contributions by Kuznets (1960) and Baron and Kahan (1975) provide ample descriptive evidence on the economic structure and life of the Jews in the $20^{\text {th }}$ century and before. Our focus is on more recent research, in this millennium, which has increased our understanding of Jewish economic history in two broad areas: first, economic specialization, and second, the causes and consequences of anti- 
Semitism. Naturally, the two are interlinked, as anti-Semitism may have affected occupational specialization, and vice versa.

\subsection{Jewish Occupational Specialization, Human Capital, and Emancipation}

The recent literature on Jewish occupational specialization and human capital primarily takes its inspiration from Botticini and Eckstein (2005, 2007, 2012), whose work has advanced our understanding of Jewish economic life over the last two millennia. Table 1 overviews this literature.

\section{[Table 1 here]}

The conventional wisdom was that Jews specialized in human-capital-intensive sectors as a result of two factors: first, Jews faced various restrictions on their economic activity (e.g., guilds did not permit them to enter certain sectors) and second, they were often not allowed to own land, and hence were less likely to permanently settle. Botticini and Eckstein challenge this view, based on novel evidence on the specialization of Jews starting at the beginning of the first millennium CE. The exogenous shock of the Roman destruction of the Jerusalem temple in 70 CE shifted Judaic focus away from the cult of sacrifice to investment in literacy. Between the $3^{\text {rd }}$ and $5^{\text {th }}$ centuries, the writing of the two Talmuds, the construction of synagogues, and the institution of the kallah (the teachers' convention) represented Judaism's considerable investment in education. Prior to the $8^{\text {th }}$ century CE, most Jews, like the rest of the population, were farmers (Botticini and Eckstein 2005). With the establishment of the Muslim Empire, literate Jews voluntarily migrated to urban areas seeking skilled employment despite no restrictions prohibiting them from remaining in agriculture. This occupational selection remained their distinctive mark thereafter.

But why did this happen? Botticini and Eckstein (2007) explain this transition into skilled urban occupations with an economic model that describes the choices regarding religious 
affiliation (remain Jewish or convert) and children's education in a world populated by Jewish and non-Jewish farmers. Education is costly not only for the individual and his family, but to the Jewish community that must raise funds to hire teachers and construct synagogues. Several options arose. The first option is that some farmers would not educate their children because they could not afford to do so, or did not see a return on their investment, or were marginally affiliated with Judaism. They converted to Hellenist paganism or Christianity with lower entry costs (no circumcision, no reading of the Torah, no required observance of the Sabbath). The second option is that farmers derived utility from Judaism, and from educating themselves and their sons. Belonging to Judaism raised their participation through education. These farmer Jews, however, had to abandon farming if they were going to get a return on their educational investment. Hence, Judaism transitioned from an illiterate agrarian religion to a literate urban one. Indeed, Jewish farmers who invested in education gained a comparative advantage and an incentive to enter skilled occupations during a period of increased urbanization in the Abbasid empire in the Near East ( $8^{\text {th }}$ and $9^{\text {th }}$ centuries). They likewise selected themselves into skilled occupations in Spain, France, England, and Germany. Both Jewish and non-Jewish merchants preferred to educate their children. However, Jewish merchants invested in their children's education comparatively more because they and their family derived direct utility from their religion.

Their earlier papers are summarized and extended in Botticini and Eckstein (2012), which covers Jewish economic history until 1492, the year in which mass expulsions of Jews from the Iberian Peninsula commenced. The key take-away from their work is that Jewish specialization in high-skilled jobs is not so much the result of external constraints set by non-Jews, but the result of an inner-Jewish battle in the first century CE which gave way to religious norms focusing on human capital acquisition. 
The work by Botticini and Eckstein clearly shows the historic roots of the Jewish emphasis on education. At the same time, it is important to take into account the specific historical and institutional context when considering the Jewish relative education advantage. In fact, two recent papers highlight that the Jewish education advantage may not be universal in all geographic and temporal contexts. In 1871 Prussia, having more Jews was associated with higher literacy in rural villages and manors but not urban towns, where a majority of Jews lived (Becker and Cinnirella 2020). A related and more nuanced finding arises in interwar Poland. Abramitzky and Halaburda (2020) document a Jewish literacy advantage in rural areas and a Jewish literacy disadvantage in urban areas. Both of these results suggest that in more recent European history, Christians in urban areas benefited from a good schooling infrastructure, leveling out any historical Jewish education advantage. Yet, in rural areas, Jews continued to stay ahead, consistent with Spitzer’s (2019) finding that Jews tended to hold similar education regardless of whether they lived in cities or in rural areas. Spitzer (2019) focuses on Jews in the Pale of Settlement, ${ }^{1}$ the region in the Russian Empire where Jews were allowed to settle, studying their occupational selection. He uses data from the 1897 Russian census to challenge the over-simplistic view that characterizes Jews as (always) an urban minority. Jewish population numbers in the Pale were substantially higher than elsewhere and Jews in this area should be seen rather as a rural service minority, with comparative advantage in countryside commerce, not in dense urban centers.

Education is only one dimension of human capital. Religious norms affect also another dimension of human capital: health. Focusing on Central and Eastern Europe after 1500, Botticini, Eckstein, and Vaturi (2019) show that breastfeeding played an important role in Judaism and was

\footnotetext{
${ }^{1}$ The Pale of Settlement included all of modern-day Belarus, Lithuania, and Moldova, much of Ukraine, parts of eastern Latvia, eastern Poland, and some parts of western Russia.
} 
one key factor in the lower child mortality rates among Jews and the resulting faster population growth among Jews. ${ }^{2}$

Although over many centuries European Jews did not enjoy equal rights to the majority populations, the $19^{\text {th }}$ century brought Jews closer to emancipation, a theme that is central to the work of Carvalho and Koyama (2016) and Carvalho, Koyama, and Sacks (2017). Both papers look into the response of the Jewish community in Germany and Eastern Europe to the opportunity afforded by increased citizen rights, in combination with differential degrees of economic development. Two polarized responses emerged. In Germany, a liberal Reform movement developed in response to emancipation, while Ultra-Orthodox Judaism emerged in Eastern Europe. Carvalho and Koyama (2016) develop a historical narrative and model of religious organization that accounts for the polarized responses by Jewish communities. Similar to Iannaccone (1992) and Berman (2000), strictness acts as a screening device for community membership. The Jewish population is composed of low attachment and high attachment types. Earned income can be spent on a consumption good or donated to the community. Furthermore, there is a tradeoff between effort and money contributions. When economic development is low (as was the case in Eastern Europe), a religious leader wants to maintain a cohesive community and does not screen out low attachment types. At higher levels of development (as in Germany), the group endogenously switches to screening, i.e., permits low attachment types to reduce effort in exchange for increased monetary contributions. In related work, Carvalho, Koyama, and Sacks (2017) show that, in Germany, non-religious and Reform Jews dramatically increased their rates of education. In the less developed parts of Eastern Europe, Orthodox and ultra-Orthodox communities imposed unprecedented restrictions on secular education and isolated themselves from society. They

\footnotetext{
${ }^{2}$ Lehrer (2008) shows how this pattern continues today when comparing educational attainment in Judaism to other religions.
} 
explain this bifurcation in a model where education not only confers economic benefits but also transmits values that undermine the cultural identity of minority groups. Johnson and Koyama (2017) consider the consequences of Jewish emancipation on economic development, proxied by city growth over the years 1400-1850. In their difference-in-differences setting, cities with Jewish communities grew about 30\% faster than comparable cities without Jewish communities. Jewish emancipation is a key mechanism to explain these results: Cities that gave increased citizenship rights to Jews earlier saw stronger population increases.

Returning to the theme of occupational specialization, several papers have looked at Jewish specialization in financial services and its long-run effects. Pascali (2016) looks at Jewish communities in Italy, the heartland of the Catholic Church. The Lateran Council of 1215 extended the prohibition of Christians to lend to each other at interest (which had previously been limited to the Catholic clergy $)^{3}$ to the Catholic laity. Moreover, Jews were silently allowed to lend at normal interest rates, carving out a niche market for them. However, Franciscan propaganda against usury became ferocious during the $15^{\text {th }}$ century and led to the creation of charitable loan banks sanctioned by the Catholic Church, called Monti di Pietà, ${ }^{4}$ that were intended to drive the Jews out of the local financial market. Their role in Italian society during the Renaissance was not markedly different from that of modern microfinance in developing countries. Pascali shows that the combination of Jewish lending and its successor in the form of Monti di Pietà were able to foster financial development and, through this channel, economic development in modern-day Italy.

Pascali's use of modern-day outcomes in connection with historic treatments is a recurrent theme throughout this chapter which is worth highlighting (see also Cantoni and Yuchtman 2020).

\footnotetext{
${ }^{3}$ The First Council of Nice in Canon VII deposed clerics who took usury from the clergy and from all ecclesiastical rank.

${ }^{4}$ For instance, Banca Monte dei Paschi di Siena, Italy’s second-largest bank as recently as 2017, was founded in 1472 as one such charitable bank.
} 
Most of the papers discussed in this section are concerned with historic developments in their own historic context. However, other papers draw on history as laboratory for current outcomes. One such example is the work by D’Acunto, Prokopczuk, and Weber (2019) which links historic antiSemitism with modern-day financial (under-)development. We will return to this in the next section.

A final fascinating agenda in recent years covers a key Jewish institution, the kibbutz, which arose from the Zionist Jewish movement in the early $20^{\text {th }}$ century. While most of the empirical work focuses on the post-WWII period, Abramitzky (2018) highlights the role played by Jewish norms, historical circumstances, and persecution in creating these communities in the 1910s and 1920s. He also studies conceptually and empirically the (lack of) stability of communes, contrasting religious and socialist communes. The former turn out to be more stable than the latter, likely because religious beliefs are more easily verifiable than socialist ones and because religious group cohesion is less reliant on equality than socialist beliefs.

Assessing the state of research on occupational specialization, human capital, and emancipation of Jews after the pathbreaking work by Botticini and Eckstein with its worldwide perspective, there is still relatively little work using individual-level, city-level, or regional data exploring Jewish life across time and space within countries.

\section{$2.2 \quad$ Jewish Persecution}

The other primary literature on Judaism in economic history focuses on Jewish persecution. Table 2 overviews this literature.

\section{[Table 2 here]}

Following up on the theme of persistence (see also Voth 2019), Voigtländer and Voth (2012) document an exceptional geographic persistence in patterns of anti-Semitism, showing that 
German cities that experienced anti-Jewish pogroms in 1348 ('Black Death pogroms') also showed higher levels of anti-Semitism in the interwar period. Similarly drawing on historic anti-Semitism, D’Acunto, Prokopczuk, and Weber (2019) find that present-day financial development is lower in German counties where historical anti-Semitism was higher, compared to otherwise similar counties. Relatedly, Grosfeld, Rodnyansky, and Zhuravskaya (2013) show that current-day residents of the former Pale of Settlement, which we touched on earlier, have lower support for the market compared to those outside the Pale. The mechanism they document is that antiSemitism generated persistent anti-market culture and trust among non-Jews.

Going beyond the long-term effects of anti-Semitism, a large body of recent research has tried to understand the causes of anti-Semitism, referring to both direct effects of economic distress and more sophisticated political-economy mechanisms. Anderson, Johnson, and Koyama (2017) employ a long panel covering 936 European cities over the years 1100 to 1800 . They show that persecutions were more likely following colder growing seasons. This effect is strongest in weak states and those with poor-quality soil. They also notice and try to explain the long-run decline in persecutions over their sample period and point to greater market integration and state capacity as one factor. Johnson and Koyama (2019) extend on these insights to provide a unifying theory of toleration and persecution. They argue that Jews and other religious minorities were "conditionally tolerated" in medieval Europe because states had low capacity and relied on religious legitimacy. This meant that although Jews were tolerated because they were useful to local rulers, this toleration could be revoked at any time, especially during periods of instability. It was only when state capacity increased and religious legitimacy became less important following the Reformation that more generalized toleration emerged. 
In related work, Finley and Koyama (2018) explore the institutional determinants of persecution by studying the intensity of the Black Death pogroms in the Holy Roman Empire. Communities governed by archbishoprics, bishoprics, and imperial free cities experienced more intense and violent persecutions than did those governed by the emperor. The political fragmentation outside areas under the emperor's rule exacerbated competition for the rents generated by Jewish moneylending, which made Jews more vulnerable during periods of crisis. Jedwab, Johnson, and Koyama (2019) analyze how the Black Death interacted with patterns of economic complementarity and substitutability. While negative shocks increased the likelihood that minorities were persecuted as shocks become more severe, the persecution probability decreased if there were economic complementarities between majority and minority groups.

The Pale of Settlement is a natural area to study questions of economic and political factors behind anti-Semitism. Grosfeld, Sakalli, and Zhuravskaya (2020) look at pogroms between 1800 and 1927 and show that ethnic violence broke out when crop failures coincided with political turmoil. Crop failures without political turmoil did not cause pogroms. At the intersection of economic and political shocks, pogroms occurred in places where Jews dominated moneylending and trade in grain.

In recent work, Jha $(2013,2018)$ argued that an ethnic division of labor is sufficient to reduce ethnic tensions when the specific advantage of a certain ethnicity cannot be replicated or expropriated by the others. Following the same spirit, economic incentives are at the core of the work by Becker and Pascali (2019). Looking at the period 1300 to 1900, they argue that the Catholic usury ban and higher literacy rates gave Jews a specific advantage in the moneylending sector. Following the Protestant Reformation (1517), Jews lost these advantages in regions that became Protestant and were exposed to competition with the Christian majority, especially in 
moneylending, leading to an increase in anti-Semitism in Protestant areas. As a long-term consequence of this shift, the share of Jews in moneylending is lower in Protestant areas of $19^{\text {th }}$ century Prussia than in Catholic areas. This latter finding is an example of the link between antiSemitism and occupational specialization.

The fate of the Jews during fascism and World War II has attracted particular attention in the literature. Since the Holocaust was engineered by Nazi Germany, it is natural to ask how the Nazis rose to power in the first place. It has long been noted that the Nazis had more support in Protestant areas of Germany. Spenkuch and Tillmann (2018) go one step further and show that constituencies' religious composition is a key empirical predictor of Nazi vote shares—dwarfing the explanatory power of any other demographic or socioeconomic variable. Their evidence suggests that this disparity was, in large part, due to the sway of the Catholic Church and its dignitaries and was helped by the fact that the Catholic Zentrumspartei (center party) held Catholic voters back from the extremes of the political spectrum.

After the Nazis rose to power in 1933, Jews came under increased pressure by anti-Semitic acts as well as laws that increasingly restricted their rights. As a result, many Jews contemplated whether to stay or leave, before their emigration from Germany was banned in 1941. While immigration restrictions made escape to certain countries difficult if not impossible, staying in Germany implied, in most cases, death in the Holocaust. Two recent complementary papers highlight the role of networks in the decision to emigrate. Buggle, Mayer, Sakalli, and Thoenig (2020) estimate a structural model of migration where individuals base their own migration decision on the observation of persecution and migration among their network of peers. The authors use individual-level data of a large fraction of German Jews in the so-called Residentenliste, the list of Jewish residents in the German Empire 1933-1945. Identification 
exploits both immigration restrictions in potential destination countries as well as the fact that Jews living in the same place of residence may learn from emigration decisions of their childhood peers at their place of origin. While covering a large fraction of Jewish citizens in Nazi Germany, the Residentenliste is short on characteristics of Jews other than basic demographics. Becker, Lindenthal, Mukand, and Waldinger (2020) focus on Jewish academics—a group whose biographies are well documented—-to study who left, when exactly, and which destinations and jobs Jewish academic émigrés chose. Emigration probabilities increase sharply with the number of colleagues who had migrated. Since networks of colleagues may be endogenously formed, for identification, the authors exploit the early dismissals of colleagues as instruments for (early) migration of colleagues. While the majority of professors were dismissed in 1933, some could stay until 1935 because they had WWI frontline experience or qualified for other exemptions. Early dismissals are a powerful predictor of early migration of colleagues and can be used to identify the causal effect of the network.

An interesting aspect of that work is that while the emigration rate of Jewish academics is well above $80 \%$, the emigration rate of the overall German Jewish population is only about $50 \%$. This positive selection by education also shows up in work by Blum and Rei (2018), who analyze passenger lists of ships leaving Lisbon for New York in the years 1940-1942. This last wave of Holocaust refugees was characterized by a large share of highly educated Jews, with selectivity by education even more pronounced than among the non-Jewish passengers.

Escaping persecution was by no means easy and often relied on the help of non-Jews. Recent studies look at the characteristics of rescuers of Jews. Hoffman (2011) looks at the "Righteous Among the Nations”, gentiles who rescued Jews and who are honored with a tree or plaque in Israel. He shows that the rescue of Jews during World War II is positively correlated with rescuer 
income at the country and the individual levels (using occupational status and self-perceived economic status as proxies for income). Given Hoffman's interest in using rescuing efforts to test for altruism, he argues that richer people had more to lose by rescuing. The positive link between income and rescuing is consistent with the view that altruism increases with income.

Contextual factors and inter-group relations have also been shown to be important in the rescue of Jews. Braun (2016) shows that minority groups are more likely to protect persecuted groups during episodes of mass killing. Using individual-level geo-coded data on Dutch Jews who escaped the Holocaust, he shows that proximity to Catholic churches increased evasion in dominantly Protestant regions, but proximity to Protestant churches had the same effect in Catholic regions. This finding is in line with his minorities-help-minorities story and shows that context matters.

While the work described so far focuses on survival and escape given the circumstances, Finkel (2015) highlights factors behind success or failure of Jewish resistance against Nazi oppression in different ghettos in Eastern Europe (Minsk, Kraków, and Białystok). His hypothesis is that successful resistance to state repression requires experience with targeted (as opposed to untargeted) repression. He shows that if there were people in the targeted population who were subject to selective repression in the preceding period, large-scale repression had a higher chance of being met with sustained organized resistance in the subsequent period.

Finally, several studies look at the legacy of the Holocaust. Focusing on Russia, Acemoglu, Hassan, and Robinson (2011) show a link between the severity of the persecution, displacement, and mass murder of Jews by the Nazis during World War II and long-run economic and political outcomes. Cities where the Holocaust was more intense have relatively lower population today and have voted in greater numbers for communist candidates since the collapse of the Soviet 
Union. The authors argue that the mechanism behind these results is the shrinking of the pre-WWII middle class in which Jews were over-represented. An unfortunate repercussion of Nazi indoctrination is its long shadow, as Voigtländer and Voth (2015) have shown for a representative sample of Germans surveyed in 1996 and 2006. Germans who grew up under the Nazi regime are much more anti-Semitic than those born before or after that period. These effects are more pronounced in districts that supported anti-Semitic parties already before 1914, i.e., where Nazism could tap into pre-existing prejudices.

As highlighted earlier, the Nazi regime dismissed Jewish academics from their positions when Hitler came to power in 1933. This might have had consequences not only for Jewish academics themselves, but also for their non-Jewish colleagues and PhD students. Waldinger (2010) provides evidence of negative effects of the expulsion of Jewish mathematics professors on $\mathrm{PhD}$ student outcomes. However, peer interactions seem to become less important in this context once scientists established a career: Waldinger (2012) finds no evidence for peer effects when looking at researchers in physics, chemistry, and mathematics. Even very high-quality scientists did not affect the productivity of their local peers. Moser, Voena, and Waldinger (2014) study the impact of the arrival of expelled Jewish chemists from Germany on US innovation activity. They show that patenting by US inventors increased significantly in émigré fields. Émigrés encouraged innovation by attracting new researchers to their fields.

The recent work on anti-Semitism in the historic social sciences using large-scale data sets has covered not only deep roots of anti-Semitism, but also its contemporaneous and long-run effects on socioeconomic outcomes. Many country-specific contexts remain unexplored with detailed micro empirical analyses. Also, the political economy of anti-Semitism in cross-country perspective remains under-studied. 


\section{Christianity}

By far the largest share of the economics of religion in history literature focuses on various aspects of Christianity. This is not surprising, given that much of this research is conducted in Europe and North America. Yet, despite the obvious importance of religion to European economic history-even schoolchildren know that the Church was one of the dominant institutions of the medieval period-only recently has Christianity been the subject of serious study by economic historians. In this section, we break these studies into three groups: Catholicism, Protestantism, and missionaries. The literature on Catholicism in economic history primarily covers the various avenues through which the Catholic Church affected economic and political life. The large literature on Protestantism largely seeks to understand the social, economic, and political causes and consequences of the Reformation. The literature on missionaries sheds light on the many longrun consequences of Catholic and Protestant missionary activity around the world, primarily in sub-Saharan Africa, Asia, and Latin America. Of these three, Protestantism has garnered most of the recent attention. The reasons for this renewed interest in Protestantism and the Reformation are numerous: a persisting fascination with Weber’s "Protestant Ethic” hypothesis, the increasing data availability via digitization, and the fact that the many political units of the Holy Roman Empire and its relative religious heterogeneity offer the type of variation needed for econometric analysis. Below we survey these recent advancements.

\subsection{Catholicism}

The literature on Catholicism in economic history primarily focuses on the many consequences of actions and doctrines promulgated by the Catholic Church. Table 3 overviews this literature.

\section{[Table 3 here]}


The Catholic Church was one of the monolithic institutions of medieval Europe. Yet, what this meant for economic outcomes is not obvious. On the one hand, the Church provided numerous goods commonly associated with economic success: poor relief, investment in (religious) infrastructure, literacy, and manuscript production. However, the most common association many have with the medieval Church is one of a greedy, anti-scientific enterprise. Much high-quality recent research has attempted to parse out the various channels through which the medieval Church affected economic activity.

One of the most important demographic-cum-economic doctrines put forth by the medieval Church affected kin marriage. Building off the pioneering study by Goody (1983), Greif (2006a, 2006b) and Greif and Tabellini (2017) argue that restrictions on cousin marriages imposed by the medieval Church facilitated the growth of institutions in which the immediate family was the focal unit. According to Goody (1983), the medieval Church sought to break kin ties in order to break up inheritances both among members of the Church (thus the medieval ban on priestly marriage) and among the laity (the Church tended to be bequeathed the land of those without heirs). Forbidding marriages between cousins (up to the sixth degree) was one way to do this, since cousin marriage was a way of keeping property in the family. As a consequence, the family unit tended to not extend much beyond the nuclear family. In contrast, places like China and the Middle East tended to have more "clan"-like arrangements, where cousins of many degrees were all part of the same social unit. While this may have limited gains from exchange within the family unit for Europeans, it also incentivized Europeans to create governance institutions that relied on cross-kin cooperation. In other words, because the immediate family was too small to take advantage of specialization or gains from trade, institutions emerged in late medieval Europe that facilitated impersonal exchange (i.e., exchange with previously unknown relations). Specifically, Greif 
(2006a, 2006b) and Greif and Tabellini (2017) argue that the more generalized morality of Christian doctrine favored (relative to China) the formation of organizations that brought together unrelated people in pursuit of a common goal. In Europe, this took the form of the corporation, which became the organizational form of choice for cities, guilds, communes, and (ultimately) business associations. Such institutions were unnecessary in the Middle East or China, where clans were the primary familial unit. Clans were large enough and tended to cover enough economic and geographic space that exchange within the clan was profitable, and social sanctions could be used to punish shirkers or those who reneged on their promises. Yet, while the clan facilitated smallscale exchange, it was inherently limited in size and scope. Thus, an unintended consequence of the Church's restriction on kin marriages was that it facilitated the growth of institutions responsible for impersonal exchange.

One such institution was the commune, i.e., the self-governed city with inclusive institutions. Schulz (2019) and Schulz, Bahrami-Rad, Beauchamp, and Henrich (2019) find that exposure to the Church (i.e., the longer that Christianity was the dominant religion) predicts the formation of self-governing communes. These communes were the types of institutions that facilitated impersonal exchange by providing an identity to those engaged in exchange that went beyond the family. Schulz (2019) shows that the Church-family association persisted for a long time: longer Church exposure still (negatively) predicts cousin marriage in the $20^{\text {th }}$ century.

An alternative (although not mutually exclusive) explanation for the rise of communes is the presence of earthquakes. Belloc, Drago, and Galbiati (2016) argue that earthquakes were dramatic, unexplainable events that were justified as acts of a vengeful God. They thus represented a shock to religious beliefs, making it easier for religious leaders to restore social order. Indeed, they find that earthquakes delayed commune development only in places governed by bishops, presumably 
because bishops had a stronger hold of their subjects than did secular rulers whose lands experienced earthquakes.

Numerous other studies look at the role of the Catholic Church in various parts of medieval and early modern economic and political life. Blaydes and Paik (2016) study the role the Crusades played in medieval state development. Crusades were expensive to fund; the Crusade tithe used to fund these ventures set a precedent for larger-scale taxation that would eventually become the hallmark of the early modern European state. Moreover, the Crusades reintegrated Europe into global trade networks (which were much more connected to the Holy Land at the time). This enabled the rise of towns which produced, consumed, and traded those goods involved in longdistance trade.

Indeed, the Church played an important role in medieval urban economic life. Richardson (2005) studies the role that religion played in strengthening the economic role played by urban craft guilds. Craft guilds were the life blood of urban economic activity. Almost all manufactured goods produced for market were produced by members of guilds. Richardson argues that guilds overcame a free-rider problem by their association with the Church. The free-rider problem faced by craft guilds arose because they desired to act like a monopolist in a certain town and produce a standardized good of a certain quality. Given weak monitoring technology, guild members were incentivized to either produce too many goods (the standard cartel problem) or produce goods cheaply, which would hurt the guild's reputation in the long run. Richardson argues that guilds overcame this problem by providing all sorts of expensive religious services (e.g., burials, prayers for souls in purgatory, feasts on saints' days) which increased the cost of expulsion from the guild.

Religious orders were institutions within the Catholic Church itself. Andersen, Bentzen, Dalgaard, and Sharp (2017) argue that the Catholic order of Cistercians favored hard work and 
thrift, in a precedent of the Protestant ethic (see Section 3.2.1). They show that in England, counties with Cistercian monasteries had faster population growth over the period 1377-1801 — even after the liquidation of the monasteries in the 1530s, which suggests cultural appreciation of hard work and thrift as a relevant mechanism. Across Europe, regions with historical Cistercian monasteries are more likely to exhibit work- and thrift-related values.

Another religious community, the Brethren of the Common Life, was founded in the late $14^{\text {th }}$ century in the Netherlands. Akçomak, Webbink, and ter Weel (2016) argue that this institutional innovation within the Catholic Church was responsible for early capitalist development in the region. Their empirical analysis suggests that the Brethren contributed not to cultural change in the Weberian sense, but rather to local human capital through providing schools, translations into vernacular, and book production. As a result, the Netherlands had much higher literacy than most parts of Europe by 1600, and was a central locus of humanist and Reformation thought.

Moving to the late $19^{\text {th }}$ century, Squicciarini (2020) finds that the French Church had a negative effect on human capital accumulation during the second Industrial Revolution. She shows that places with significant Church penetration were more likely to have their school curricula influenced by the Church, which at that time promoted a relatively anti-scientific program. Such a curriculum would not have had a large effect on economic output in the period prior to the second Industrial Revolution, since high-human capital labor was not overly complementary to capital prior to this time. However, the types of technologies that emerged in this period increased the returns to technical knowledge, so that places with high Church influence-and thus a slower introduction of the technical curriculum—suffered economically.

These results are broadly consistent with the idea that the French Church was a hindrance to development, an issue also studied in Finley, Franck, and Johnson (2019). They look at the effect 
of the massive redistribution of Church land that resulted from the French Revolution. They find that areas in which more Church land was redistributed had greater productivity in the first half of the $19^{\text {th }}$ century, suggesting that these regions were underutilized when under Church control. Uribe-Castro (2019) also studies the effect of the redistribution of Church land, in this case in $19^{\text {th }}$ century Colombia. He finds that places in which Church land was expropriated had much less political violence in the ensuing decades. This was due to changing political alliances: where the Church was strong, it pitted liberals versus conservatives, the latter of whom aligned with the Church. Where the Church was weakened, differences in policy preferences were not as stark, and conflict was less common.

Although the Reformation has been subject to immense study in recent years by social scientists (see Section 3.2), the Counter-Reformation has seen relatively little study, even though its long-run impact on European history and economic history is immense. The CounterReformation was the Catholic Church's (delayed) response to the Reformation. It began with the Council of Trent (1545-1563) and lasted through the Peace of Westphalia in 1648. In this period, the Church increasingly allied with secular authorities to put down (often violently) rising Protestant sentiment. The Counter-Reformation sparked massive religious conflict in this period, most notably the Thirty Years' War (1618-48), the most violent conflict on European soil until the $20^{\text {th }}$ century. Ekelund, Hébert, and Tollison (2002) argue that the Church was a monopolist provider of spiritual goods that used its position to place its members on the margin of defection, thus opening the gates for the success of the Reformation (see Section 3.2.2). This insight reflects the broader point made in Ekelund et al. (1996) that various practices of the medieval Church make sense if one views the Church as a firm. They lay out the "industrial organization of the Church" to understand why the Church interfered in marriage markets, promoted doctrine limiting 
economic exchange (i.e., usury and price restrictions), instigated Crusades, and used monastic agents. Building on these insights, Ekelund, Hébert, and Tollison (2004) suggest that, following the initial success of the Reformation, the Church acted like an incumbent firm trying to fight new entrants: it rewrote its corporate charter (e.g., the Council of Trent) in response to the new market conditions. However, the Counter-Reformation largely failed because entrenched interests within the Church—the pope and the college of cardinals—-had too much power that would have been relinquished with any type of major reform like those demanded by the Protestants. One of the ways in which the Church attempted to suppress the Reformation and "maintain its monopoly position” was to suppress books via the Index Librorum Prohibitorum (Index of Prohibited Books). Becker, Pino, and Vidal-Robert (2019) find that the Index did indeed reduce the output of forbidden authors. They also find that cities which defied the Index grew faster and attracted more famous people.

The previously mentioned studies analyze the effect of the Church, its institutions, or its doctrine on economic outcomes. A smaller literature seeks to understand the reverse: the effect of economic conditions on Church doctrine. Barro and McCleary (2016) provide an analysis of the determinants of the beatification and canonization of Catholic saints. They find that beatification and canonization responds to numerous incentives, including religious (a pope’s tenure, a region's Catholic population), political (Catholic-Protestant competition), and historical (the stock of already-canonized saints from a region) circumstances.

Among the most well-known of the economic doctrines of the Church are those related to usury, i.e., taking interest on loans. Rubin (2009) studies the origins of usury prohibitions in the late Roman Empire. Usury was not always banned by the Church; the first widespread denunciation of usury occurred at the Council of Nicaea in 325. Rubin argues that the usury ban 
can be seen in the light of a commitment problem faced by the Church, which became wealthy after the Emperor Constantine adopted Christianity in 312. The Church had previously provided social insurance to its entire flock, and because it was relatively poor could commit to only providing to the "deserving poor" (i.e., those who had not taken excessive risk). With a much larger budget, it could no longer commit to this policy, which encouraged moral hazard among Christians, such as taking excessive loans. The Church responded by banning interest, which prevented such individuals from obtaining risky loans in the first place. Koyama (2010) also studies the Church's medieval usury restrictions. He argues that the Church continued to enforce the usury ban long after its original intentions were relevant due to an equilibrium which emerged between merchants, rulers, and the Church. In this equilibrium, the usury ban was a barrier to entry that permitted a small number of merchants to make monopoly rents, which were partially siphoned by rulers and the Church. Although the usury ban placed some restrictions on merchants' activities, those with a first-mover advantage preferred these restrictions because they were even more onerous on their competitors. One silver lining of the usury ban, at least for Catholics, is that it may have reduced anti-Semitism. Since Catholics were discouraged from lending openly at interest, Jewish lenders filled this role, meaning there was little direct competition between Catholics and Jews. However, as Becker and Pascali (2019) show (see Section 2.2), Protestants did not abide by the usury ban, putting them in direct competition with Jews in the lending market, which contributed to persistent anti-Semitic attitudes amongst Protestants.

The recent work on Catholicism in history primarily focuses on the various ways in which the Catholic Church affected economic, demographic, and political outcomes. With the exception of a few papers, it is relatively silent on the role of the Church, Catholic doctrine, or other Catholic institutions in the post-Reformation era. 


\subsection{Protestantism}

When Martin Luther composed his 95 Theses in 1517, he triggered the Protestant Reformation, which led to the persistent split of the Protestant denominations from Catholicism. A large body of recent research focuses on the socioeconomic consequences of the Protestant Reformation, as well as its socioeconomic causes. We highlight leading contributions here; a more extensive recent survey is provided by Becker, Pfaff, and Rubin (2016).

\subsubsection{Socioeconomic Consequences of the Reformation}

Theories of the consequences of the Reformation date at least to Max Weber and his wellknown "Protestant ethic" thesis. In the last two decades, this literature has seen a massive resurgence. Table 4 overviews this literature.

\section{[Table 4 here]}

In his seminal contribution on the socioeconomic effects of Protestantism, The Protestant Ethic and the Spirit of Capitalism, Max Weber (1904/05) famously argued that there is a particular Protestant ethic that was instrumental in facilitating industrial capitalism. ${ }^{5}$ In contrast to the Catholic ideal of surpassing worldly morality in monastic asceticism, Weber argued that the notion of the "calling” introduced by the Reformation sanctified labor as a task set by God, thereby creating a Protestant work ethic that valued the fulfillment of worldly duties as a moral achievement. By approving the accumulation of wealth, the Protestant ethic provided the moral foundation for capitalist industrialization, with economic success regarded as a sign of God's salvation. Important mechanisms by which the Protestant ethic is argued to further economic progress include hard work and thrift. While the Weber thesis has created a lot of controversy, not

\footnotetext{
${ }^{5}$ Weber traces back his central notion of a Protestant “calling” to Martin Luther but sees it more strongly developed in other Protestant denominations, such as Calvinism and Puritanism.
} 
least about its correct interpretation, a commonly adopted simple interpretation of its economic bearing is that the Protestant ethic furthered economic development.

As an alternative to the Weber thesis, Becker and Woessmann (2009) propose a human capital theory of Protestant economic history. They argue that Martin Luther urged his followers, including the Protestant rulers, to advance education so that they could read the Bible. As a side effect, higher levels of education served as human capital in the economic sphere, increasing productivity and economic development. Using distance to Wittenberg as an instrument for Protestantism that exploits the initial concentric dispersion of the Reformation in Prussia, Becker and Woessmann find that Protestantism led to higher literacy across Prussian counties in the late $19^{\text {th }}$ century: the average literacy rate in Protestant-majority counties was $90 \%$, 8 percentage points higher than in Catholic-majority counties. They also show that Protestant counties had higher income and higher non-agricultural employment. Both in a horse race and in a bounding analysis, their results suggest that the higher literacy of Protestants is able to account for most of the Protestant economic advantage over Catholic regions of Prussia. In supplementary analyses, Becker and Woessmann (2010) show that the effect of Protestantism on education is already visible in early $19^{\text {th }}$ century data, ruling out a Weberian interpretation where better education just resulted from industrialization, and Becker and Woessmann (2008) show that the effect was particularly pronounced among girls, decreasing the gender gap in basic education. In a crosscountry analysis, Becker and Woessmann (2009) show that a positive association between Protestantism and economic development mirrors a strong positive association between Protestantism and literacy across countries in 1900.

Using variation in the share of Catholics and Protestants across Swiss districts in the late $19^{\text {th }}$ century, Boppart et al. (2013) also find a positive association of Protestantism with education in 
terms of educational spending per student and educational performance. This association is stronger in regions with conservative milieus, as measured by votes on different referenda. Using data on pedagogical examinations of military conscripts across Swiss districts, Boppart, Falkinger, and Grossmann (2014) show that the effect of Protestantism was particularly strong for reading, but also extended to essay writing, math, and history.

By affecting the population's education, Protestantism also led to changes in the historical development of other socioeconomic outcomes. Using Wittenberg-induced variation in education, Becker, Cinnirella, and Woessmann (2010) show that education led to a reduction in fertility across Prussian counties in the mid- $19^{\text {th }}$ century. Education in 1849 also predicts the fertility transition at the turn to the $20^{\text {th }}$ century. This link from education to fertility is a crucial factor for the transition from Malthusian stagnation to sustained growth in unified growth theory (Galor 2011). The evidence suggests that the demographic transition may in part reflect an indirect effect of Protestantism.

Using factory employment data for Prussian counties from the early, mid, and late $19^{\text {th }}$ century, Becker, Hornung, and Woessmann (2011) focus on the adoption of the new industrial production technologies and the major transformation of the economic structure brought about by the Industrial Revolution. Both in cross-sectional models that exploit pre-industrial variation in education and in panel models with county fixed effects, they show that education increased industrialization in the metal sector and in other sectors outside metal and textiles (such as rubber, paper, and food), but not in the textile sector. The effect on the non-metal/non-textiles sectors is visible in both phases of the Industrial Revolution, whereas the effect on metalworking factories is strongest in the second phase (1849-1882). These results are confirmed in specifications that use 
distance to Wittenberg as an instrument for education, thereby exploiting variation in the education of the native population induced by Protestantism.

A different source of religiously induced variation in the skilled population stems from the religious persecution that led to the mass migration of French Protestants - the Huguenots - to Brandenburg-Prussia in 1685. Hornung (2014) argues that large parts of the Huguenot population were skilled in textile production and brought technological knowledge with them. Using plague losses during the preceding Thirty Years' War as an instrument for the settlement of the Huguenots, he shows substantial positive effects of Huguenot settlement in 1700 on the productivity (value of output per inputs) of textile manufactories one hundred years later. The immigration of skilled Protestants thus appears to have led to the long-term diffusion of better technology before the Industrial Revolution.

Apart from the work on Protestantism and education, the literature continuous to create controversy about Weber's thesis of a Protestant ethic. While the human capital results of Becker and Woessmann (2009) leave little room for alternative mechanisms in line with the Weber thesis (such as work effort and savings propensity), results in other settings cover the whole spectrum from questioning the economic advantage of Protestant regions in the first place to aspects consistent with the Weber thesis to ethical interpretations beyond the Weber thesis.

Using a panel of cities in Germany over the period 1300-1900, Cantoni (2015) does not find that cities that converted to Protestantism after the Reformation show a different path of the size of their city population compared to cities that did not. Compared with the results in Becker and Woessmann (2009), this may suggest that the effect of Protestantism on economic outcomes may have been restricted to areas outside the major cities, where literacy was relatively high independent of religious denomination. 
Studying church ordinances introduced with the Reformation in German cities, Dittmar and Meisenzahl (2020) focus on the interaction between religious competition and local political economy. They argue that the introduction of church ordinances—which acted as public goods institutions that expanded welfare provision and public education-was facilitated by the interaction of the global shock of the Reformation, which introduced religious competition, with shocks to local politics that facilitated political action by citizens. Using plague incidents as an instrument for the adoption of church ordinances, their empirical analysis shows that cities that were induced to adopt church ordinances attracted and produced more upper-tail human capital over the period in 1520-1819 (as measured by the number of individuals documented in the Deutsche Biographie, a collection of biographies of famous Germans) and show a larger increase in city population from 1500-1800. They argue that the adoption of public goods institutions, rather than the adoption of Protestantism per se, accounts for the different population development.

Another approach to study long-run effects of the historical adoption of Protestantism is to use contemporary German data. Using territories’ official religion as defined by their princes’ religion around 1624—-the "normal year" of the Peace of Westphalia—as an instrument for contemporary religious affiliation, Spenkuch (2017) draws on the historical variation in Protestantism in the aftermath of the Peace of Augsburg. Results suggest that historical Protestantism is associated with longer working hours, but not higher hourly wages, today. This is interpreted as evidence consistent with a value-based interpretation, as in the Weber thesis.

The use of contemporary data also allows researchers to focus on direct measures of preferences for work and political intervention. Using a spatial discontinuity in the Swiss cantons of Vaud and Fribourg created by a $16^{\text {th }}$ century split between Catholicism and Reformed (Calvinist) Protestantism, Basten and Betz (2013) study votes in modern-day referenda and find 
that the historically induced split is associated with lower political preferences of Protestants for increased leisure time, redistribution, and government intervention. Beyond preferences, the Protestant regions show higher inequality and (weakly) higher income. The results are interpreted as being in line with the Weber thesis of a Protestant ethic.

Studying effort provision of German WWII soldiers as proxied by military decorations, promotions, injuries, and deaths, Beatton, Skali and Torgler (2019) find that Protestants outperform Catholics, and Calvinists outperform Lutherans, which they interpret as consistent with a Protestant work ethic. Blum and Strebel (2016) study body height in a sample of Germans born between 1910 and 1924. They find that while height was lower among those born during WWI for both Protestants and Catholics, the decrease of Protestants' height was smaller, which is interpreted as higher resilience of Protestants to war-related deprivation.

Another mechanism by which the Protestant Reformation may have spurred economic development is the reallocation of investments in human and physical capital from religious to secular purposes. Cantoni, Dittmar, and Yuchtman (2018) argue that the new religious competition shifted political power from religious to secular authorities, which gained wealth from the closure of monasteries especially in Protestant regions. ${ }^{6}$ As a result, in the immediate aftermath of the Reformation, graduates of Protestant universities tended to choose secular (administrative) majors and occupations rather than religious ones, and construction shifted from religious buildings to secular palaces and administrative buildings, particularly in Protestant regions. The results suggest that the Protestant Reformation triggered secularization processes.

A related institutional consequence has been highlighted for the English Reformation. Heldring, Robinson, and Vollmer (2017) show that the dissolution of English monasteries in 1535

\footnotetext{
${ }^{6}$ See Becker, Pfaff, and Rubin (2016) for work on effects of the Reformation on political governance more generally.
} 
created a more efficient allocation of agricultural resources and helped bring about the Agricultural Revolution. They also find a positive relationship between monastic land holdings and industrialization around the time of the Industrial Revolution.

Beyond its effects on different aspects of economic and educational development, several studies also point to potential negative socioeconomic consequences of the Reformation. Durkheim (1897) documented that Protestant countries and regions had higher suicide rates and suggested the religious individualism of Protestantism as a mechanism. While Catholics' unified community embedded them socially, the Protestant doctrine promoted independent thinking, making Protestants less reliant on their religious community. In addition to this social-cohesion channel, Becker and Woessmann (2018) also model a religious-beliefs channel in an economic theory of religion-specific suicide: Catholic doctrine emphasized more than the Protestant one that the deadly sin of suicide prevented access to paradise in afterlife. Again exploiting the concentric dispersion of Protestantism around Wittenberg, they show that suicide rates are significantly larger in Protestant compared to Catholic Prussians counties in the early and late $19^{\text {th }}$ century. The effect is large: Protestantism increased the annual suicide rate by about $15-20$ suicides per 100,000 inhabitants, compared to a mean of 13 suicides. Tests of the two suggested mechanisms by which Protestantism increases suicide propensity suggest that the sociological channel is more relevant than the theological channel: among others, using historical church attendance data the authors show that the suicidal tendency of Protestants is more pronounced in areas with low church attendance, indicating that the strongest effect is found in areas with little social integration rather than in areas with high devotion to the Protestant doctrine.

Recent studies also indicate that the Protestant Reformation may have led to an increase in anti-Semitism. As discussed in Section 2.2 above, Becker and Pascali (2019) indicate an increase 
in Jewish persecution in Protestant areas, and Spenkuch and Tillmann (2018) document Protestantism as a leading predictor of Nazi vote shares.

It has also been argued that Catholic-Protestant competition was a leading source of witch trials. Leeson and Russ (2018) show that witch-trial activity is positively associated with confessional battles in a panel of 21 European countries observed at the decadal level over the period 1500-1699. The association is robust to the inclusion of country and decade fixed effects.

In sum, the recent burst of work on how the Reformation affected historical economic developments highlights the role of human capital in Protestant economic history, which was interrelated with increasing income, productivity, industrialization, secular resource use, and reduced fertility. At the same time, the emergence of Protestantism also affected the incidence of suicides, anti-Semitism, and witch trials. The empirical bearing of a particular Protestant ethic remains subject to continuing controversy.

\subsubsection{Socioeconomic Causes of the Reformation, of its Spread, and of Protestant Religiosity}

The combination of advances in digitization along with the variation in the adoption of the Reformation (especially in the Holy Roman Empire) has made it possible to econometrically study the causes of the spread of the Reformation. Table 5 overviews the emerging literature that addresses this topic.

\section{[Table 5 here]}

Substantial recent work on the causes of the Protestant Reformation has highlighted factors both on the supply side and on the demand side of the market for religion. Luther's open deviation from the Roman Catholic Church in 1517 triggered extensive religious conflict. Wide-ranging choices of territorial rulers to adopt the new denomination or to remain Catholic were institutionalized by the rule "cuius regio, eius religio" (whose realm, his religion) in the Peace of 
Augsburg (1555). When the Peace of Westphalia finally terminated the savage Thirty Years' War (1618-1648), it guaranteed the religious status quo of the "normal year" 1624. Analyses of the causes of the spread of Protestantism range from its early adoption during Luther's time to the subsequent diffusion of the Protestant faith. ${ }^{7}$ In addition, secularization analyses study causes of the later decline in Protestant religiosity.

The initial successes and failures of the Protestant Reformation have been studied in the framework of an industrial-organization model. Ekelund, Hébert, and Tollison (2002) argue that the monopolistic practices of the medieval Catholic Church encouraged the entry of Protestantism as a competitor. The Catholic Church placed many consumers of spiritual services on the margin of defection by manipulating doctrine to increase its revenues, excluding rivals, and performing price discrimination. Their key hypothesis is that entrepreneurial societies where feudalism was in decline and the distribution of wealth was unstable facilitated the entry of Protestantism. By contrast, homogeneous rent-seeking societies that dissipated rather than created wealth repressed Protestant entry, and the Catholic Church could continue to price discriminate. Consistent with this model, the authors descriptively show that societies with partible inheritance laws that likely catered to a wider wealth distribution embraced Protestantism, whereas societies ruled by primogeniture were more likely to remain Catholic.

Relational factors appear to have played a role in the diffusion of the Protestant Reformation. Kim and Pfaff (2012) argue that, depending on whether the universities that students attended mobilized them for the new denomination or were loyal to the Catholic Church, university students acted as facilitators or blockers of the religious reform movement in their home towns. The authors show that cities in the Holy Roman Empire that had more students enrolled in universities in

\footnotetext{
${ }^{7}$ A more encompassing discussion of the causes of the Reformation, its spread, and the political economy of religion in Western Europe on the eve of the Reformation is given in Becker, Pfaff, and Rubin (2016).
} 
Protestant strongholds (Wittenberg and Basel) and less in Catholic strongholds (Cologne and Louvain) in 1517-1522 were more likely to institute the Reformation (abolish or reform the Catholic Mass) in 1523-1545.

Another source of relational diffusion is the role of Martin Luther himself as a social entrepreneur. Becker, Hsiao, Pfaff, and Rubin (2020) study social proximity to the ideological leader in his personal network. They show that cities with personal ties to Luther-measured by having received a letter from Luther, having been visited by Luther by 1522, or being home to one of Luther's students—-had a higher probability of being Protestant in 1530. Results of simulation models are consistent with the view that the early spread of the Reformation resulted from a combination of Luther's personal ties with spatial diffusion along contemporaneous trade routes.

Exploiting the high territorial fractionalization of the Holy Roman Empire, Cantoni (2012) studies which German territories and cities chose to adopt the Protestant Reformation by 1600 . He finds that territories more distant from Wittenberg (as in Becker and Woessmann 2009), under ecclesiastical rule, and with more political and economic power (measured by contributions to the federal budget of the Holy Roman Empire) were less likely to become Protestant. The findings of a spatial panel model are consistent with a theory of strategic neighborhood interactions where conversion was less risky if a strong neighbor had already done so.

Another argument is that conversion to Protestantism had a larger appeal to local authorities of territories that had more to gain from the institutional change, as it provided legitimacy for secular governance and allowed the use of resources for local and secular purposes. Using the same setting as Cantoni (2012) of German cities in 1600, Curuk and Smulders (2019) show that the adoption of Protestantism was positively associated with agricultural potential (based on climatic suitability and soil quality) and negatively with population size in 1500 . The results are 
interpreted as consistent with a Malthusian model of untapped economic potential and thus the potential benefits of regime change.

Yet another theory is that the printing press facilitated the spread of the Protestant Reformation. The reformers used printed materials to propagate their cause. Because of high transportation cost, these materials spread through reprinting, so that the existence of a printing press increased access to Reformation ideology. Using distance from Mainz—where Gutenberg had invented the printing press-as an instrument, Rubin (2014) shows that having a printing press by 1500 increases a city's likelihood of adopting Protestantism by 1600 by at least 29 percentage points. Extending the analysis, Boerner, Rubin, and Severgnini (2019) show that the adoption of the printing press had even deeper roots, as cities that had adopted mechanical clocks early on were also more likely to adopt presses early. But while the effect of the printing press on the adoption of the Reformation was direct, the effect of the clock was only indirect via the press.

It has also been argued that competition in the printing industry affected the content of the printed material and thereby the adoption of the Reformation. Dittmar and Seabold (2020) classify printed books in the period 1454-1600 by their denominational orientation. Arguing that recent printer deaths provide a source of exogenous variation in the competitive environment in the local printing market, they show that higher competition in printing before the Reformation increases the spread of religious media and of Protestant content during the Reformation in a sample of German-speaking cities. This diffusion of Protestant content increased the likelihood that a city adopted the Reformation.

Political economy factors have also been shown to be relevant for the spread of the Reformation. Iyigun (2008) argues that the survival of the Protestant Reformation was facilitated by Ottoman incursions. As described in greater detail in Section 4.1 below, he shows that the 
number of conflicts in which the Ottoman Empire confronted European powers is negatively associated with the number of violent conflicts within continental European countries over the period 1450-1700, and in particular with those of Catholic-vs-Protestant religious nature over the period 1521-1650.

Beyond the initial adoption of the Reformation, recent studies have also used Protestantism to test leading theories of determinants of religiosity. Classic secularization hypotheses suggest that different dimensions of modernization, including economic and educational development, affect religiosity. Marx (1844) famously portrayed religion as "opium of the people" that was needed only to alleviate the misery of poor economic circumstances.

In their study of the relation of income and secularization, Becker and Woessmann (2013) exploit a historically unique indicator of churchliness provided by the headcounts of participations in Holy Communion that are contained in the Sacrament Statistics of the statistical surveys of the Protestant Regional Churches of Germany on the Expressions of Churchly Life. In a panel of Prussian counties over the period 1886-1911, they show a marked decline in church attendance among the Protestant population that coincides with increasing income. However, the association between income and church attendance disappears in panel models with county and time fixed effects, as well as in long-term first-differenced models and in panel Granger-causality tests. The findings provide no indication that the reduction in religiosity at the turn to the $20^{\text {th }}$ century was the result of improved material conditions.

Others have argued that education and science would lead to a decline in religion because increased critical thinking and advanced scientific knowledge may reduce belief in supernatural forces (e.g., Hume 1757; Freud 1927). Becker, Nagler, and Woessmann (2017) combine religious attendance data from the same source with school enrollment data for a panel of German cities 
between 1890 and 1930. In panel models with fixed effects for cities and time, they find that the expansion of advanced-school enrollment was positively associated with subsequent reductions in church attendance. No such effects are found for income and urbanization. The relationship between educational expansion and declining church attendance is as strong for classical humanist grammar schools as for newly emerging upper secondary schools with a curricular focus on natural sciences, consistent with an important role for general critical thinking-which may have undermined belief in the institutionalized church—rather than specific scientific knowledge of facts of natural sciences. More broadly, similar to the effect of Protestantism on the secularization of occupational choice and resource investments in the immediate aftermath of the Reformation shown by Cantoni, Dittmar, and Yuchtman (2018), these results indicate that the expansion of education brought about by Protestantism may have laid the foundation for an ultimate decline in the importance of the church in everyday social life.

In sum, many supply-side and demand-side factors of the market for religion appear to have contributed to the adoption and spread of the Protestant Reformation. Monopolistic practices of the medieval Catholic Church, relational factors, strategic neighborhood interactions, economic potential, technological factors like the printing press, and political-economy factors like Ottoman incursions all appear to have played a role. Tests of secularization hypotheses indicate a role for education, but not income, in reduced church attendance of Protestants during the secularization phase at the turn to the $20^{\text {th }}$ century.

\subsection{Missionaries}

While most of the research on Christianity in economic history is concerned with European countries, another important strand of the literature considers the role of Christian missionaries outside Europe. Exploiting the recent data collection efforts on missions around the globe 
pioneered by Robert Woodberry (2004), researchers have looked at whether the presence of missionaries had long-term effects on modern-day outcomes. ${ }^{8}$ Table 6 overviews this literature.

\section{[Table 6 here]}

Most of this literature focuses on the effects of missionaries on human capital and health. Evidence comes from Africa, Asia, and Latin America, which we cover in turn. We close with studies looking at a broader range of outcomes and at the dynamics of missionary expansion.

Much of the evidence on positive effects of missions on education and health comes from subSaharan Africa. Gallego and Woodberry (2010) provide evidence that regions in former Colonial Africa in which Western Protestant missionaries dominated have higher literacy rates than those where Catholic missionaries dominated. ${ }^{9}$ They also highlight the importance of competition: where missionaries competed, they provided more services like schools and health centers. Nunn (2014) finds that Protestant and Catholic missionary activity in Africa both had long-term positive impacts on education, although women profited more in Protestant areas. Studying colonial Benin, Wantchekon, Novta, and Klašnja (2015) show that missionaries increased the valuation of education in families close to historical mission stations. Their results indicate that missionaries even changed the values of non-Christians in the same village, suggesting human capital externalities. Studying long-term health effects in Uganda, Doyle, Meier zu Selhausen, and Weisdorf (2020) show that (mostly Protestant) Christian African converts adopted healthier sexual behavior during the colonial period. Cagé and Rueda (2020) qualify the overall positive image of

\footnotetext{
${ }^{8}$ See Woodberry (2011) for an early survey on the literature on missionaries. The literature on missionaries and education is more extensively covered in recent surveys for Africa by Meier zu Selhausen (2019) and for Latin America and Asia by Valencia Caicedo (2019b).

${ }^{9}$ This is consistent with the finding of Becker and Woessmann (2009), who point to a Protestant advantage in literacy in $19^{\text {th }}$-century Prussia and in a cross-section of countries in 1900.
} 
missionaries: while they were the first to invest in modern African healthcare, Christianity influenced sexual beliefs and behaviors that affected the risk of HIV contagion.

In many cases, missionary activities took place alongside colonial conquest and the introduction of legal and economic institutions. This raises the question of what is the counterfactual to missionary activity: no missionary activity but still a presence of colonial institutions, or no foreign presence at all? While this question is often neglected, a rare exception is the work by Wietzke (2015), who exploits historical differences in the timing and organization of historical school investments and colonial legal-institutional reforms in Madagascar. Christian missionaries introduced formal schooling several decades before the imposition of French colonial rule and were thus unrelated to the economic or military objectives of the colonizers. Results indicate that colonial institutions had comparatively stronger effects on local economic outcomes than missionary school investments.

The question of missionary activity versus colonial activity does not arise in the case of China, where missionary activity initially happened outside any colonial context. After 1580, the Jesuits introduced European sciences to China, where the intelligentsia was dominated by Confucian literati who lived largely in autarky. Ma (2020) demonstrates that the Jesuits stimulated Confucian literati to study science. However, effects do not persist after the Jesuits were expelled by the emperor of China in 1723. Looking at a later period of missionary activity, Bai and Kung (2015) find that Chinese regions that had higher penetration of Protestant missionaries during the $19^{\text {th }}$ century also had higher urbanization rates at the beginning of the $20^{\text {th }}$ century. The mechanism identified by the authors is knowledge diffusion activities associated with schools and hospitals erected by the missionaries. 
Additional evidence of positive effects of missionaries on education and health comes from India. Calvi, Mantovanelli, and Hoehn-Velasco (2019) show that Protestant missionaries in India are associated with higher literacy. Similarly, current health outcomes are better the closer a village is to historical Protestant medical missions (Calvi and Mantovanelli 2018). Using Catholic missions as an instrumental variable to look at the effect of completed secondary education in India today on night light intensity, Castelló-Climent, Chaudhary, and Mukhopadhyay (2018) show a positive link between Catholic missions and completed secondary education. They explain the seeming contrast with Calvi, Mantovanelli, and Hoehn-Velasco (2019) by showing that Protestant missions affect completed middle school, but have no effect on other education levels, such as completed secondary schooling.

The Latin American experience allows to study the effects of different kinds of Catholic missionaries. Waldinger (2017) examines the long-run effects of different Catholic missionary orders in colonial Mexico on educational outcomes. She shows that different monastic traditions pursued different aims and transported different values. Mendicant orders were committed to poverty and sought to reduce social inequality in colonial Mexico by educating the native population. The Jesuit order, by contrast, focused educational efforts on the colony's elite in the city centers, rather than on the native population in rural mission areas. Mendicant orders left a lasting mark in the Mexican countryside with higher educational attainment in areas where they held a stronger historic presence.

Jesuits were, in contrast, very influential among the Guarani people whose homelands straddle three South American countries—Argentina, Brazil, and Paraguay. Jesuit missions in South America instructed indigenous inhabitants in reading, writing, and various crafts. While the Jesuits were expelled from the Americas in 1767, Valencia Caicedo (2019a) shows that, in areas of former 
Jesuit presence, educational attainment was higher and remains so 250 years later, compared to areas outside the Jesuit reach.

Beyond effects on human capital and health, some work has looked at effects of missionaries on a broader range of outcomes. Nunn (2010) provides evidence that foreign missionaries altered the religious beliefs of Africans, and that these beliefs persist as they are passed on from parents to children. The results indicate that Christian missionaries had a lasting impact on culture. Woodberry (2012) highlights the role Western Protestant missionaries played in influencing the rise and spread of stable democracy around the world. Cagé and Rueda (2016) combine the direct influence of missionaries with the technology that some missionaries brought with them in the form of the printing press. They show that, within sub-Saharan African regions close to main European missions, proximity to a printing press is associated with higher newspaper readership, trust, education, and political participation.

While much of the literature links historical Christian missionary activities to various socioeconomic outcomes, only recently has focus shifted to better understanding the dynamics of missionary expansion per se. Meier zu Selhausen (2019) gives a comprehensive account of Christian missionary expansion in Africa during the colonial era. He emphasizes the Africanization of the mission, i.e., the fact that much of the effect of Christian missionary work should be attributed not to the first European missionaries, but to their local followers and supporters who expanded missionary activities into territories not reached before. This theme is also at the core of the work by Jedwab, Meier zu Selhausen, and Moradi (2019), who study the drivers and long-term consequences of Christian missionary expansion across colonial Africa, with a particular emphasis on Ghana. Their paper reassesses the reliability of widely used data sets of missionary activity 
based on early missionary atlases ${ }^{10}$ and conclude that they miss $90 \%$ of the missions in early colonial Africa. Investigating the local determinants of missionary expansion, the authors show that missions expanded initially within more developed, healthier, safer, and more accessible areas. Reassessing the long-term effects of Christian missions in Ghana by reconstructing the full set of missions for the period 1751-1932, the authors conclude that the effect of Christian missions on modern African economic development was much more moderate.

While most of the numerous recent advances in research on Christian missionaries indicate positive long-term impacts of Christian missionaries worldwide, some caveats remain. Certain religious norms (such as Catholic opposition to family planning) may have negative consequences for economic development. Importantly, selection of missionaries into different locations gives rise to endogeneity concerns that have not always been fully addressed. Another understudied area is research on different streams within one religion, such as different Catholic missionary orders (Waldinger 2017 being one exception) and different types of Protestantism. ${ }^{11}$

\section{Islam}

In the last two decades, economists have become increasingly interested in the economic history of the Islamic world. Indeed, the topic has now been studied enough to warrant a survey piece in the Journal of Economic Literature (Kuran 2018). There are multiple reasons for this increased interest. For one, the Islamic world has played a central role in world politics and economics, with the aftermath of 9/11, the Arab Spring, and outflows of Muslim immigrants into

\footnotetext{
${ }^{10}$ Widely used sources for missionary activity are the 1900 Atlas of Protestant Missions (Beach 1903) and the 1924 Ethnographic Survey of Africa (Roome 1925).

${ }^{11}$ McCleary (2013) has cautioned against equating all forms of Protestantism as equally beneficial for human capital acquisition. In Guatemala, Evangelical, Pentecostal, and neo-Pentecostal denominations and churches focused their efforts on evangelizing, emphasizing eschatological urgency of conversion with little investment in human capital.
} 
Europe among the many important events. Understanding the role that history and Islam have played in these events is of clear importance. Moreover, new sources of data and econometric techniques have allowed social scientists to answer questions that were previously answerable only via qualitative methods.

The biggest question addressed in this literature is at the heart of the research program spearheaded by Timur Kuran (which culminated in his 2011 book, The Long Divergence): why did the Middle East fall behind the West economically after being ahead for so long? Works asking this question fall into the greater debate regarding the "great divergence" between the West and the

rest of the world. These works tend to focus on three themes: i) politics and law; ii) finance and trade (and its impediments); and iii) the human capital deficit of the Islamic world. In this section, we overview recent works which address each of these topics.

\subsection{Politics and Law}

Since its inception, Islam has been intertwined with politics and law. Much of the literature analyzing the economic consequences of Islam naturally focuses on this aspect of Islam and Islamic institutions. Table 7 overviews this literature.

\section{[Table 7 here]}

Over much of the history of the Islamic world, religion has played an important role in politics. In the early Caliphates - the First Four Caliphs following Muhammad (632-661) and the Umayyad Empire (661-750) — the line between political and religious leader was blurred. Rulers claimed religious authority, and there was no independent religious establishment to speak of. This changed under the Abbasid Empire (750-1258), when the religious establishment asserted its independence and began to play a role in politics as a player separate from the ruling elite. This arrangement was 
common in many parts of the world ruled by Muslims, including North Africa, the Middle East, and Central Asia (and to a lesser extent, South Asia).

Rubin (2017) hypothesizes that the legitimating relationship between rulers and the Muslim religious elite can account for numerous long-run economic outcomes. In his framework, religion is one of many tools rulers have to stay in power because of the legitimacy it provides. Muslim rulers have historically used religious authorities as a central source of legitimation because Islam is relatively effective at legitimating rule. Islam emerged conterminously with an expanding empire that was in need of legitimation, and there are consequently numerous Islamic doctrines consistent with the idea that a ruler should be followed as long as he acts like a "good Muslim." Blaydes, Grimmer, and McQueen (2018) reveal the importance of religious legitimation in a study of political advice texts in the Muslim and Christian worlds. They analyze the texts from the medieval period and find a break around the $12^{\text {th }}-14^{\text {th }}$ centuries: after this point, Muslim rulers were advised to increase religious appeals while there was a decline in such advice to Christian rulers. According to Rubin (2017), this increased emphasis on religious legitimation gave religious authorities a stronger seat at the political bargaining table, which meant that their preferences were reflected in policy. Coşgel, Miceli, and Ahmed (2009) present a similar framework based on the legitimating role of Islam in a political economy equilibrium. They focus on the relationship between religious legitimacy and tax collection and how this affected the ruler's relationship with the legal community. Kuru (2019) likewise argues that this "ulema-state" alliance kept the bourgeoisie and intelligentsia out of political decision-making in the Islamic world after the $11^{\text {th }}$ century, to the detriment of the region’s long-run economic development.

The confluence between religion and political legitimacy had numerous consequences. Rubin (2017, ch. 5) and Coşgel, Miceli, and Rubin (2012) employ these insights to answer one of the big 
puzzles of Middle Eastern history of technology: why did the Ottoman Empire ban the printing press for over two centuries, foregoing what was ostensibly a free lunch? A framework relying on the legitimating power of religious authorities makes sense of this puzzle. Religious authorities stood to lose their monopolies over intellectual output and the interpretation of religious works had the printing press spread (fears that were justified by events happening in Europe). Yet, it was rulers, not religious scholars, who had the coercive capacity to prohibit the printing press. The reason that Ottoman rulers agreed to do so-despite the numerous economic and propaganda benefits offered by the press—-was that anything that would undermine the religious establishment would also undermine their capacity to rule.

Chaney (2013) presents evidence from medieval Egypt, consistent with the political economy framework described above, in which religious authorities play a central role in legitimating the state. Chaney provides evidence that religious authorities became more powerful in medieval Egypt when the Nile River was either too low (meaning drought) or too high (meaning flooding). He provides evidence that, under these conditions, the tenure of religious authorities was longer and they received more policy concessions. While Chaney argues that this is because religious authorities were able to coordinate rebellions, a related explanation has to do with their role in legitimating rule. Periods of drought or flooding are precisely when rulers were in the direst need of legitimacy, and thus the bargaining power of religious authorities was greatest. Ticku, Shrivastava, and Iyer (2020) find evidence of a similar mechanism in historical India, showing that historical economic shocks are associated with Muslim desecration of Hindu temples. Like Chaney's finding, a likely cause is that desecrations were an attempt to employ the legitimating power of religion in times of instability. 
Blaydes and Chaney (2013) present a hypothesis for the divergence between the Christian West and the Islamic world that is related to the ones laid out above. They argue that the different types of groups that negotiated and constrained rulers played an important role in the long-run political and economic trajectories of the regions. Specifically, Muslim rulers' access to slave soldiers-a non-hereditary class which had little power to constrain rulers-meant that they did not have to negotiate with other segments of society. According to Chaney (2019), the relative lack of constraint on Muslim rulers was a residue of the Arab conquests and the tribal modes of governance that spread in its wake. This favored the rise of military slavery, the decay of secular bureaucracy, and, ultimately, the emergence of an influential class of religious scholars. Chaney (2019) reasons that in the first decades of Islam, tribal elites were able to use the fiscal systems of recently conquered populations to their own ends, developing a military system of slave soldiers that would be the predominant military form in the Muslim world for over a millennium. As Blaydes and Chaney (2013) argue, this reduced the power of other elites to bargain with and constrain rulers. Meanwhile, weaker European rulers had to cede much to their feudal elites in return for military service and revenue. The authors argue that this meant greater stability for European rulers, who faced a lower threat of revolt due to a larger set of interests having a seat at the political bargaining table. Indeed, they show that beginning with the feudal revolution of the Carolingian Empire (around the $9^{\text {th }}$ century), the tenure of European rulers became increasingly longer than of those in the Islamic world, in large part due to the latter being subject to revolt. One consistent thread in all of the research cited above is that the relationship between rulers and those who keep them in power-religious or not-matters for long-run economic and political development. 
Jean-Philippe Platteau has also proposed theories relating the legitimating rule of Islamic religious authorities to economic and political outcomes. His primary focus, however, is on the horizontal structure of Islamic institutions in relation to the more hierarchical, vertical institutional structure of the Catholic Church. Auriol and Platteau (2017) and Platteau (2017) propose a theory suggesting that when rulers have to negotiate with hierarchically-structured religious authorities (such as the Catholic Church), they only have to appease those at the head of the hierarchy, and the rest of the religious class will follow. In other words, rulers have to appease the average cleric. On the other hand, when rulers have to negotiate with decentralized religious elites (as in Islam), they will co-opt a fraction of them (depending on their desired policy choices). In other words, their choices are made to co-opt the marginal cleric. Auriol and Platteau argue that this means that hierarchical religions are associated with more stable political regimes, since there is a smaller set of clerics who will revolt against the ruler. Moreover, decentralized religions are more often associated with theocracy, as rulers attempt to gain the support of a large fraction of the religious establishment and thus propose policies to satisfy its most extreme elements. Platteau (2017) supports this theory with great detail from historical Muslim polities throughout the world.

Another key feature of Western religions is monotheism, and the "one true God" doctrine it entails. Iyigun (2015) argues that rulers who are legitimated by one of the monotheistic, Abrahamic religions face existential threats when confronted by enemies of opposite faiths. Unlike conflict between co-religionists, a goal of inter-faith conflict is to spread the message of the "one true God," which would undermine the prevailing religious-political equilibrium. This is why, as noted in Section 3.2.2, Iyigun (2008) argues that the Catholic Habsburg Empire felt the pressure to deal with the Ottoman threat rather than the looming Protestant Reformation: Ottoman conquest would have fundamentally undermined the existing social and political order, whereas the intra- 
Christianity threat posed by the Protestants, while dangerous, was not existential. Iyigun (2013) provides additional support for this hypothesis by studying the relationship between the religion of the Ottoman sultan's mother (who was generally a slave in the harem) and Ottoman conflict with Europe. When the sultan's mother was Christian—as was frequently the case—conflict with Europe was much less likely.

In a series of articles which culminated in his 2011 book The Long Divergence, Timur Kuran has spelled out one of the most important economic consequences of these dominant political arrangements in the Islamic world: religious authorities maintained purview over commercial law, i.e., commerce was subject to Islamic law. One unforeseeable consequence of this arrangement was that two aspects of Islamic law—regarding partnerships and inheritance—contributed to the persistent simplicity of Islamic business organization. Kuran (2005) argues that two features of these laws were salient. First, partnerships dissolved upon the death of any of the partners. Second, Islamic inheritance law entailed a pre-ordained split among numerous heirs. Hence, while one’s heirs could re-form a partnership upon the death of their benefactor, this was subject to the heirs not needing the funds for other pursuits, which was not always assured. Combined, these laws provided disincentive to form large, long-lasting partnerships. As a result, the institutional evolution that occurred in Europe-which helped solve problems such as short-lived enterprises and unlimited liability—never emerged in the Islamic world.

Alternative institutions did exist, however. Kuran (2001) notes that the waqf (pious trust) served many of the same functions as the corporation: it was long-lived and relatively free from confiscation by the grabbing hands of rulers. Waqfs were trusts endowed by wealthy individuals that provided public goods such as water fountains, schools, or poor relief. They lived beyond their founder, while partnerships did not. They were also relatively free from confiscation because there 
was a pious element associated with their founding, which increased the cost to rulers from confiscating their funds. Yet, there were two problems with waqfs which prevented them from transforming into organizations akin to the corporation. First, waqfs became an attractive means of evading Islamic inheritance law. If one did not want their estate split among multiple heirs, one could endow a waqf and pay one of their heirs a handsome salary to run it. This ostensibly entailed funneling one's inheritance to one (or a few) desired heir(s). Second, waqf law placed severe restrictions on the extent to which one could change the mission of the waqf. For instance, a waqf that was established to fund a madrasa (educational institution) was only permitted to fund that madrasa in perpetuity, even if alternative uses of the funds became available over time. This restrictive nature of the waqf meant that it was unlikely to be used for business purposes, which required more flexibility.

Kuran and co-authors reveal another aspect of Islamic law that had a dampening effect on economic activity: it was partial in favor of men, elites, and Muslims. Kuran and Lustig (2012) show that Ottoman courts were biased in favor of these groups, and that inter-faith and inter-class commerce suffered as a result. If those who faced bias knew that they would have a difficult time winning restitution, they were unlikely to enter into transaction in the first place. Kuran and Rubin (2018) extend this logic to the credit market. They show that Muslims, men, and elites paid 1.93.4 percentage points higher interest rates on loans, presumably because they could renege with impunity and were thus greater credit risks.

Another important policy that was ubiquitous throughout early Muslim empires was the taxing of non-Muslims at higher rates. Saleh (2018) shows that in Egypt this policy had the effect of creating selection among converts to Islam. Poorer Coptic Christians converted to Islam to avoid paying the tax, while wealthier Copts could afford to pay the tax and tended not to convert. Over 
time, this led to Copts being a well-off minority with greater human capital and other characteristics of high socioeconomic standing. Saleh and Tirole (2019) build on this idea with a model of the tradeoffs faced by a ruler who desires both tax revenue and conversion to Islam. They show that it can be optimal for rulers to operate on the downward-sloping part of the Laffer curve, since extraordinarily high tax rates (which do not maximize total revenue) serve to induce conversion to Islam.

In sum, the literature suggests that Islam and Islamic institutions have played an important historical role in the political economy of the Middle East. A variety of consequences of this role are apparent, including relative economic backwardness, conflict with Christian Europe, and relatively slow adoption of new technology and economic institutions. This literature is mostly concerned with the Middle East and North Africa. Extending these insights to other parts of the Muslim world, including South, Central, and Southeast Asia, should be a fruitful area for future research.

\subsection{Finance and Trade}

Given the role of Islamic law-especially commercial law-in political economy outcomes, it is not surprising that Islam affected finance and trade. The literature has sought to understand some of the mechanisms through which this connection arose (to the extent that it exists at all). Table 8 overviews this literature.

\section{[Table 8 here]}

Beyond its role in politics, Islam has been shown to affect numerous aspects of finance and trade. Perhaps most famously, Islam prohibits the taking of interest. Rubin (2011) provides an institutional reason for why interest prohibitions remained in Islam-even if they were easy to evade-but not in Christianity, which prohibited interest for over a millennium but gradually 
relaxed the prohibition in the medieval period. Rubin argues that an equilibrium emerged in the Islamic world in which religious authorities permitted interest as long as a sufficiently costly ruse was undertaken, ${ }^{12}$ political authorities allowed what was permitted by religious authorities, and merchants (and other economic elites) lent at interest while at least paying lip service to the ruse. There were multiple consequences of this equilibrium, which persisted until at least the $18^{\text {th }}$ century in the Ottoman Empire. First, Rubin (2017) points out that it almost certainly inhibited the indigenous growth of banking in the Middle East, or any type of activity in which deposits were openly taken and interest paid on those deposits. Indeed, the first bank in the Middle East was not formed until the mid- $19^{\text {th }}$ century, and it was built using European capital.

There were other, unforeseeable, consequences of interest restrictions. Rubin (2010) shows that they affected how bills of exchange emerged in the Middle East and Western Europe and contributed to financial development. In Europe, bills of exchange were used as financial instruments to skirt the Church's usury restriction, and doing so required inter-regional trade (since profit was made by taking advantage of differences in exchange rates). This encouraged the growth of large-scale, inter-regional organizational forms that could take advantage of the opportunities provided by bills of exchange, such as the Medici enterprise of the $15^{\text {th }}$ century. This encouraged the economic elite to engage in impersonal exchange-and to build organizations capable of carrying out impersonal exchange-since the benefits to long-distance exchange with unknown parties were much greater. In the Islamic world, however, the interest ban prevented bills of exchange (known as suftaja) from ever being used in such a manner, and thus the institutional

\footnotetext{
${ }^{12}$ A classic example of a ruse is the double sale, whereby one party would sell a good to another and then immediately buy it back for a higher price payable at a later date. This is ostensibly a loan with interest, but the ruse must be undertaken for it to be considered valid.
} 
evolution that occurred in Europe never did in the Middle East, and exchange largely remained personal (i.e., with known relations) until the modern period.

Another example of the long-run consequences of interest restrictions is provided by Grosjean (2011), who shows that historical interest restrictions still affect financial development today, even in locations where they are no longer in place. Using within-country variation in the extent to which the Ottoman Empire ruled in Southeastern Europe, Grosjean finds that even though economic development in general is not associated with historical Ottoman rule, financial development is: former Ottoman rule is associated with a $10 \%$ lower bank penetration across countries and $4 \%$ lower penetration within countries. The Islamic ban on interest is provided as the most likely cause of these results.

Islam also affected trade through inter-religious conflict, or lack thereof. Jha (2013) provides evidence from South Asia, where Hindus and Muslims have lived together since the first century of Islam. He finds that a history of economic interdependence, which was especially stark in Indian port towns due to the dominance of Muslim traders in the medieval period, were much less prone to Hindu-Muslim riots between 1850 and 1995. Jha argues that the channel connecting old trade routes to modern-day outcomes are economic institutions that fostered positive interactions—and thus inter-ethnic trust—-between members of the two religions. These institutions had a persistent effect on the occupational structure of South Asia, which may have affected conflict. It may have also had an effect on important health outcomes like polio vaccinations. After a rise in beliefs in the early 2000s that polio vaccinations are a vehicle for minority male sterilization, Muslims tended to vaccinate their children less throughout India. This inter-religious difference did not arise, however, in medieval port towns (i.e., those with a history of positive economic interactions), where there was no difference in Muslim and Hindu vaccination rates. 
In fact, trade may have been important to the initial spread of Islam. Michalopoulos, Naghavi, and Prarolo (2018) find that the spread of Islam is associated with proximity to pre-Islamic trade routes. They argue that multiple mechanisms associated with Islamic religion and society may account for this phenomenon. First, the prevalence in Islam of direct trade, whereby traders would travel with their goods instead of trade through intermediaries, can account for the more personal ties that were made around the time of the initial spread of Islam. Moreover, this encouraged merchants to trade with co-religionists, who often shared a common language and were subject to similar institutional constraints, thus increasing trust among the parties.

Furthermore, Michalopoulos, Naghavi, and Prarolo (2016) show that the type of trade and the associated geography of early Islamic expansion had an effect on the type of religious doctrine formulated at this time. Specifically, since Islam spread along trade routes, this ultimately entailed the possibility of predatory behavior, as inequalities due to different factor endowments were exacerbated by trade, leaving the wealthy areas prone to attack from the poorer ones. In order to overcome this issue while maintaining the trade possibilities opened up by Islam, early Islamic doctrine sought redistributive mechanisms, such as zakat (charitable giving), to reduce the predatory incentive.

Another example of the long-run effects of conflict in the Muslim world is provided by Chaney and Hornbeck (2016), who analyze the long-run effects of the 1609 Morisco expulsion by the Spanish. Following the expulsion, Spain experienced sharp population declines in places where Moriscos were populous, and in the short run experienced decreased output and increased per capita output (as predicted by Malthusian models). Yet, the authors show that Malthusian convergence (to pre-expulsion conditions) was delayed for nearly two centuries in former Morisco districts. They propose that extractive institutions in Morisco areas persisted after the expulsions, 
which would have discouraged the level of in-migration necessary for Malthusian conditions to arise. They cannot rule out cultural differences, however; since Christians tended to have fewer children, married older, and lived more lavishly, Malthusian dynamics possibly took a longer time to arise than they would have had the Morisco population not be expelled.

Moving to the $18^{\text {th }}$ and $19^{\text {th }}$ centuries, a couple of studies indicate that special trade privileges given to European traders may have been responsible for exacerbating the economic differences between the two regions. Kuran (2004) argues that the long-standing tradition of Ottomans permitting religious minorities to adjudicate disputes in their own courts (unless one of the parties was Muslim) had little impact on economic development until the $18^{\text {th }}$ century, when for the first time European organizational forms became vastly superior. Once Europe pulled ahead, legal pluralism gave Europeans a distinct advantage over Muslims, who were forced to adjudicate disputes in Islamic courts. Muslims could thus not employ the more advanced organizational forms created in Europe if they wanted to have access to the court system in case of dispute. Differential access to economic institutions within the Ottoman Empire thus likely contributed to the economic divergence. Artunç (2015) shows that this differential access to courts was part of a larger Ottoman policy of selling exemption licenses (called berats) to Europeans. These tax exemptions were unavailable to Muslim Ottomans. Because foreign, non-Muslim merchants had these institutionalized advantages over domestic, Muslim merchants, by the early $19^{\text {th }}$ century berat holders dominated Ottoman trade.

In sum, Islamic doctrine was both caused by and has since caused financial developments in the Muslim world. This includes usury restrictions, trade complementarities, and legal pluralism. Each of these developments may shed some light on the relative reversal of fortunes between Western Europe and the broader Muslim world. Importantly, these studies are distinct from 
"Islamic economics" or "Islamic finance," both of which are inventions of the $20^{\text {th }}$ century and seek to understand economics and finance within an Islamic theological context.

\subsection{Human Capital}

A final part of the economic sphere in which Islam has affected outcomes is human capital accumulation. The literature on this topic largely seeks to understand the role religion and religious institutions (madrasas) play in incentivizing human capital accumulation. Table 9 overviews this literature.

\section{[Table 9 here]}

For the first four to five centuries after the spread of Islam, literature and science in the Islamic world were vastly superior to that of Western Europe. At some point in the late medieval period, however, Europe caught up with and eventually far surpassed the Middle East (and the rest of the world). Chaney (2016) provides a massive amount of data detailing this reversal of fortunes. He shows that the proportion of books dedicated to scientific topics declined dramatically in the Islamic world in the medieval period, mostly at the expense of religious texts. The reversal is starkest in the $11^{\text {th }}$ and $12^{\text {th }}$ centuries, just as madrasas begin to spread throughout the Islamic world. Chaney argues that this reflected the "Sunni revival" of the period, in which religious leaders gained significant political power. Since the payoff to religious production was much greater than that of scientific production, many of the great Middle Eastern minds of the period entered the religious establishment. Importantly, it is unlikely that religious leaders were directly responsible for the decline in scientific productivity. The reversal was more of a bottom-up process (i.e., fewer great minds going into science) rather than a top-down process directed from above.

Moving to the $19^{\text {th }}$ and $20^{\text {th }}$ centuries, Saleh (2015) provides evidence for the role that Egyptian industrialization played in attenuating human capital differences between Christians and Muslims. 
He finds that the first wave of industrialization (beginning in 1848) resulted in a "deskilling" of Muslims and an "upskilling” of Christians, likely because the pre-ordained spatial (urban/rural) composition of the various religious populations and the number of administrative jobs open to Christians in the government. However, there was an upskilling of both religious groups during the second wave of industrialization (beginning in 1868), in part because more Muslims became “medium skilled”, while many Christians became high skilled. Saleh (2016) provides further insight into Christian-Muslim human capital differences in Egypt by examining a massive transformation of traditional (religious) schools into modern primary schools in the early 1950s. He finds that Muslims benefitted significantly from the reforms, while Christians were unaffected. This is likely because of the religious curriculum in traditional (pre-reform) schools, which tended to leave Muslim students ill-equipped for the job market. Relatively few Christians attended these schools prior to the reforms, and hence the reforms had the effect of leveling the playing field between students of the two religions.

There is similar evidence for the role of religious schools in generating human capital differences between Hindus and Muslims in colonial India in the early $20^{\text {th }}$ century. Chaudhary and Rubin (2011) find that the parts of British India that had a more recent collapse of Muslim rule had lower Muslim literacy, although Hindu literacy was not affected. They surmise that religious authorities had more power in places with more recent collapse of Muslim rule, and thus Muslim religious schools were more prevalent. Since Muslim religious schools were not as effective at providing literacy, those regions had fewer literate Muslims. Chaudhary and Rubin (2016) focus on the Indian Princely States (i.e., those not directly ruled by the British). They find that states with Muslim rulers had lower Hindu literacy, but there was no effect on Muslim literacy or other public good provision. They suggest that rulers provided fewer public goods when there were 
privately-provided substitutes that were excludable by religion. Numerous Muslim religious schools existed on the continent, and hence Muslim rulers would have provided less funding towards public education to the extent that they were motivated by supporting their co-religionists.

In sum, the historical legacy of Islam on human capital outcomes tends to be negative, although there is limited evidence of catch up in the $20^{\text {th }}$ century. This statement comes with an important caveat: the relationship between Islam and human capital is vastly understudied. To the extent that human capital accumulation played any role in the rise of the modern economy or the long-run divergence between Western Europe and the Muslim world, this is a major shortcoming of the literature. Of the many mechanisms through which Islam may have played a role in economic development, human capital accumulation seems to be among the most ripe for researchers to study.

\section{Cross-country Studies}

Beyond the study of specific religions in different country settings, some studies exploit the wider historical variation in religions and religiosity that exists across countries. These studies use either variation across different world religions or variation in religiosity that pools individuals from different religions. The cross-country studies have analyzed both economic causes and consequences of religion. Table 10 overviews this literature.

\section{[Table 10 here]}

In terms of consequences of religion, Young (2009a) revisits the association between Protestantism and economic development at the country level. Looking at the GDP per capita of Protestant and Catholic countries in Europe over the period 1500-2000, he shows that Protestant countries — which had been behind Catholic countries before the Reformation—outperformed the Catholic countries by 1700, even before the Industrial Revolution. For more than 250 years, their 
income was substantially higher than that of the Catholic countries, with an increasing gap until about 1870, when it stabilized. Only since the 1960s did the Catholic countries start to converge. This research follows cross-country work on religion and economic growth by Barro and McCleary (2003) for the post-WWII period (1965-1994). Barro and McCleary find that economic growth is positively associated with religious beliefs in heaven and hell but negatively with church attendance across countries. ${ }^{13}$

In many Western countries, state school systems emerged during the $19^{\text {th }}$ century that aimed to serve all children. West and Woessmann (2010) document that the Catholic Church strongly opposed this secular development, urging Catholics to educate their children in non-secular Catholic schools. They show that the historical resistance to state schooling persisted: countries that had higher Catholic shares in 1900 (but did not have Catholicism as a state religion) continued to have substantially higher private school shares in 2003. The authors exploit this historical source of variation in private schooling in a cross-country student-level analysis to show that private competition improves students' academic achievement (which, in turn, has been shown to improve economic prosperity across countries (Hanushek and Woessmann 2015)). The positive effect of Catholic-induced school competition runs counter to any direct positive effect of Protestantism on educational achievement (a cross-country pattern described in Becker and Woessmann 2009), which West and Woessmann account for with contemporary data on religious shares.

Turning to cross-country analyses of economic causes of religion, Franck and Iannaccone (2014) use retrospective questions posed in two waves of the International Social Survey Program (ISSP) in the 1990s to study religious decline in a panel of ten Western countries over the period

\footnotetext{
${ }^{13}$ Replicating these findings, Durlauf, Kourtellos, and Tan (2012) find that the relationship of church attendance and economic growth is robust across a variety of statistical specifications, whereas the relationship of religious beliefs and economic growth is not (see also Young 2009b).
} 
1925-1990. ${ }^{14}$ Estimating panel models with country and time fixed effects, they find that church attendance is negatively associated with government spending on education, whereas other factors such as government spending on health and family, urbanization, income, and educational attainment do not enter the model significantly. The authors interpret the results as indicating lack of support for traditional theories of secularization or crowd-out by welfare states, but being consistent with a role for state indoctrination in schools. In their analysis of determinants of state religions, Barro and McCleary (2005) show a strong element of historical persistence in state religions in that having a state religion in 1900 predicts having a state religion in 1970 and 2000, in particular in countries that did not have a major regime change over the period.

To test whether religious coping—i.e., turning to religion in times of hardship—can account for global differences in religiosity, Bentzen (2019) combines individual-level data on religiosity from the World Values Survey and the European Values Study with data on earthquake incidences across 884 subnational districts in 85 countries. Her results indicate that individuals in districts closer to high-risk earthquake zones are more religious, and that different measures of religiosity increase after an earthquake hit a district (also when including country-by-year fixed effects).

In sum, cross-country studies of religion in economic history have highlighted the global relevance of religious affiliations and beliefs for economic and institutional development. Government educational spending and earthquake shocks have been highlighted as determining factors of religiosity in a cross-country perspective. While posing substantial challenges to convincing identification, steps forward in cross-country comparative work could help form a broader picture of the role of religion and religiosity in economic history.

\footnotetext{
${ }^{14}$ This work follows on prior cross-country work by McCleary and Barro (2006a, 2006b, 2019) studying determinants of religiosity in the post-WWII period (1981-1999).
} 


\section{Conclusion}

The rise of the economics of religion has met the digitization revolution affecting the study of economic and social history (Abramitzky 2015; Mitchener 2015) to create a new but rapidly growing subfield: religion in economic history. Much of this recent research has focused on the three Abrahamic religions and how some of their salient religious norms have influenced socioeconomic outcomes.

Jewish economic history has been studied both in the Jewish homeland as well as in the diaspora. There are two primary aspects of Jewish history studied in the literature: the Jewish edge in human capital accumulation and Jewish persecutions. In the human capital literature, a key finding is that the Jewish focus on high-skilled occupations is not so much the result of their minority status and persecution in the diaspora, but the result of religious norms on reading the Torah. Similarly, Protestants have emphasized the need for every Christian to read God's word for themselves. These two religious groups have been shown in many contexts to be better educated than Catholics or Muslims. Studies of Christian missionaries confirm the Protestant education lead over Catholics when contrasting long-term effects of missionary presence on education outcomes in colonial countries. Jewish educational differences affected various outcomes like occupational specialization and income.

Jews have always constituted a minority outside their homeland, and discrimination and ethnic violence have been a recurrent theme in their history. Anti-Semitism has shaped Jewish life for centuries and has been shown to be persistent as a result of both cultural and economic factors. The period of Jewish emancipation in the $19^{\text {th }}$ century in many European countries brought with it a bifurcation between Orthodox and Reform Judaism that has been widely studied. This period came to a tragic end with the fascist period and the Holocaust that eliminated Jewish life in vast 
parts of Europe. The research described has studied the causes and consequences of anti-Semitism in many different countries.

The literature on Catholicism focuses largely on the role the institutionalized Church played in various economic outcomes. This includes prohibitions on cousin marriage and usury, as well as human capital accumulation in monasteries and religious schools. The Church was also a major political player in the medieval and early modern periods. The literature addresses some aspects of Church involvement in politics, such as guild participation and the Counter-Reformation.

The largest literature in the field of religion in economic history is on Protestantism. This is in part due to continued fascination with Weber's Protestant ethic hypothesis. It also has much to do with the digitization revolution that has made available massive amounts of data from the Reformation period and beyond. It is likewise reflective of the enormous political and religious heterogeneity of the Holy Roman Empire- the birthplace of the Reformation and the setting for much of its study — which allows for the variation needed to test for effects empirically. The literature on Protestantism can broadly be placed into three categories: causes of the Reformation, consequences of the Reformation for human capital and industrialization, and the Protestant ethic. These studies almost all have an empirical emphasis. While some reveal limited support of Weber's Protestant ethic hypothesis in certain contexts, others suggest that there is a human capital channel connecting Protestantism with economic success. Several economic, social, political, and technological factors have been shown to have contributed to the adoption and spread of the Reformation.

The economics of Islam literature largely focuses on the ways that Islam has affected economic outcomes via law or politics. Islam is a legalist religion and Islamic law has been the law of the land in much of the "Islamic world" throughout history. Various works have shown how the 
presence of Islam in law and politics has affected economic outcomes such as corporate development, usury restrictions, conflict, finance, and human capital development. Much of this literature studies the Western Islamic world: Turkey, North Africa, and Muslim Spain.

When looking across these recent contributions to the study of religion in economic history, a few themes run through these works. First, the "empirical/credibility revolution" that has dominated much of the economics literature over the last two decades has greatly influenced work on the economics of religion in history. Most of the papers surveyed are empirical and use econometric or methodological techniques to address causality, such as instrumental variables, differences-in-differences, or natural experiments. This was clearly not the case when Iannaccone wrote his 1998 survey on the economics of religion. At that time, most papers in the field were either applications of rational-choice theory or analyses of survey data. In several cases, the use of new methodological approaches and fine-grained data reversed prior correlational findings based on coarser data. Second, many of the works seek the "deep roots" of larger economic differences between regions and religious communities. This is the case with respect to works on the prosperity of Jews, Jewish persecutions, Protestant-Catholic differences, Muslim-Christian differences, human capital development, cultural attitudes, doctrinal differences, legal development, and financial development. Third, a primary reason religion seems to matter so much in economic history (at least for places practicing Abrahamic religions) is that religion and politics are often intertwined. This connection manifests itself in legal systems, state capacity, religious persecution, investments in religious vs. secular education, and economic organization. Fourth, human capital has played a key role in the economic history of all three Abrahamic religions.

While these general themes provide some overarching structure, it has also become evident from the survey that parts of the recent literature are somewhat eclectic and fractionalized, focusing 
on specific aspects and scrutinizing individual relationships—as should be expected in a recently emerging field. It is fair to say that in several areas, a unifying picture of the socioeconomic causes and consequences of religion and religiosity in economic history still needs to be developed.

While the religion in economic history literature has blossomed over the last decade, there are still many low-hanging fruits for future generations of scholars to pick. Perhaps the most obvious is studies of non-Abrahamic faiths. Studies on non-Abrahamic, and in particular polytheistic, religions in economic history are relatively rare. This may be due to language barriers—most of the scholarly work in the field to date, with the exception of some work on Islam, studies parts of the world that speak European languages. But this is all the more reason for scholars to study the other religions. We know relatively little about the economic consequences of the roles that Hinduism and Confucianism, or other religions such as Buddhism and Shintoism, played in politics. We also know little about their effect on human capital accumulation. Given the importance of religion for politics and human capital accumulation in the Abrahamic faiths, these seem like natural questions to ask.

In particular, Hinduism seems ripe for study using modern methodological and data-collection techniques. Its importance in world history as well as the contemporary world is undeniable: there are currently around 1.1 billion Hindus worldwide, accounting for $15 \%$ of the world's population. Moreover, through the caste system Hinduism arguably has had as much of a direct impact on economic outcomes as any major world religion. However, unifying economic analyses of Hinduism are largely lacking. Although economists have long been interested in the caste system (e.g., Akerlof 1976), and Deepak Lal's 1988 book The Hindu Equilibrium placed Hinduism in a broader social, economic, and historical context, there is precious little work using cutting-edge data-collection and econometric techniques. This is a missed opportunity. Not only is Hinduism 
important in its own right, but the massive amount of variation on most socioeconomic and political dimensions on the Indian subcontinent makes rigorous analysis feasible (much as is the case with the Holy Roman Empire in the literature on the Reformation).

Even rarer is work on ancient, pre-historical religion. Anthropologists have long been fascinated with why societies worship different types of gods (moralizing, punishing, etc.) and what this means for cooperation, coordination, and markets (e.g., Shariff, Norenzayan, and Henrich 2010; Henrich et al. 2010; Norenzayan 2013). Societies have always struggled to solve these key economic features. Bringing this line of work into economics and economic history should yield enormous insight into the role that religion and religious beliefs can play in historical and contemporary socioeconomic outcomes.

Even within the Abrahamic faiths, the literature has numerous blind spots. One vastly understudied religion is Shi'a Islam. We know little about its economic consequences in places like Iran, whether via politics, human capital accumulation, or any other economic outcome. ${ }^{15}$ Within Sunni Islam, relatively little work has been done on the role that tribes and extended kin groups have played in affecting the evolution of Islam and Muslim economies. Given the recent importance placed on kin groups in the Christian world (e.g., Greif and Tabellini 2017; Schulz, Bahrami-Rad, Beauchamp, and Henrich 2019), this seems like a fruitful topic for future research. Likewise, we know relatively little about the role of the Orthodox Christian Church in the economic history of Eastern Europe. Another under-researched topic are possible socioeconomic determinants of the emergence and spread of Christianity in the first place, and (beyond the work on the Protestant Reformation) how new religions more generally do or do not spread successfully.

\footnotetext{
${ }^{15}$ Shi'a Islam has not been ignored altogether. For example, Jha's (2013) study of trade complementarities between Muslims and Hindus in South Asia focuses in part on Gujarati Hindus who converted to Ismaili Shi'a Islam in the $11^{\text {th }}$ century.
} 
Surprisingly, we also know relatively little about the role that religion played in the development of the US economy. This is surprising for multiple reasons. To the extent that the sociology of religion literature of the 1980s and 1990s focused at all on history, it tended to be US history (e.g., Finke and Stark 2005). Moreover, US data tend to be richer and publicly available. While some recent studies have focused on the US—-such as Ager and Ciccone (2018) on religious communities and agricultural risk, and Xiong and Zhao (2020) on the link between religious fragmentation and the establishment of colleges-there are no common themes in the recent literature.

We suspect that one reason so little research has been conducted on certain religious faiths is a lack of data availability. Consistent, clean, and insightful data are simply more easily available in some places than in others. For instance, so much work on Islamic economic history has been done on Sunni Islam in general and Turkey in particular because of the meticulous record-keeping done by the Ottomans. ${ }^{16}$ As early as the $15^{\text {th }}$ century, the Ottomans kept detailed court records from the major Istanbul courts. Many of these records still exist today and are available to researchers (who know Ottoman Turkish); Kuran (2010-13) has translated many of the $17^{\text {th }}$ century records into English in a ten-volume set. Meanwhile, verdicts and contracts in Iran were not written down until the late $19^{\text {th }}$ century. Contracting tended to be oral, with witnesses rather than documents called to reproduce facts. This is likely why there is very little quantitative economic history of Iran, the Persians, or the Shi'a Safavids.

The next generation of religion in economic history is also likely to take advantage of technological advancements to use methodologies and data that were unavailable to previous generations of scholars. Even in the case of the Istanbul court documents, these data were only

\footnotetext{
${ }^{16}$ We thank Timur Kuran for making this point to us.
} 
very recently constructed in a manner that could be useful for the social scientists, and a large fraction of the archives remains undocumented in a systematic way. New and better technology provides promise to alleviate this issue. The digitization revolution and progress in computer linguistics have opened new opportunities to employ text as data (Gentzkow, Kelly, and Taddy 2019), which opens a big opportunity for historic research. Given the scarcity of historic censuses and the near absence of census-type data before 1800, researchers have often drawn on city-level data because, if anything, cities might have had the infrastructure to collect data earlier on. Of course, written records have been at the heart of research in economic history, including religion in economic history. But text as data may be the next big step to systematically explore written records. For instance, the Vatican archives hold vast amounts of documents that have only been accessed in a piecemeal approach, and using them in their entirety by employing natural language processing could shed light on the workings of the longest-running major religious institution in history.

A systematic exploration of alternative data sources may also provide new insights about religious and economic life outside of cities. Many historical studies use city-level data because they are the most widely available. Yet, in doing so they arguably miss insights into the role that churches, mosques, and clerics played in the life of the vast majority of the population living in the countryside. Moreover, even if technology provides us with the opportunity to digitize data that used to be more difficult to collect, there is still the issue of finding these data in the first place. This is no small task, especially for cross-country or cross-religion comparisons where data are not systematized or held in one place. Such data collection efforts would be of enormous use to the broader research community but are also expensive to conduct. Fortunately, funders like the National Science Foundation and John Templeton Foundation have shown a willingness to fund 
such data collection efforts in the past. It will take a diverse set of scholars in terms of background, languages, and institutional knowledge, but this is an area with enormous potential.

Future work can also take advantage of new technology to document the reach and power of institutionalized religion over time and space. There have been efforts to document the universe of church building activities in selected countries, e.g., Denmark (Paldam and Paldam 2017). Buringh, Campbell, Rijpma, and van Zanden (2020) study church building and economic development during Europe's 'Age of the Cathedrals,' 700-1500. This work partly draws on the data collection efforts of enthusiastic hobbyists (e.g., OpenStreetMap) who make geo-coded data of places of worship, past and present, available on the web. Similar efforts to document the reach of churches, synagogues, and mosques in other countries, as well as systematic evidence on the presence and features of places of worship in other religions, would be a fruitful avenue to document the influence of institutionalized religion over space and time.

Another method that may bring future advances in the field is network analysis, which has seen a recent surge of interest in economic history (Esteves and Mesevage 2019). Little of this work has looked at religious networks, but it seems natural to try to understand the rise and fall of religions or specific denominations in light of network theories. Network analysis may also be used to gain deeper understanding of the spread of doctrine, religious dissent, and human capital.

Religious history can also serve as a useful testing ground for theories in various fields of economics. For instance, the industrial-organization approach which has been applied to the behavior of churches might prove fruitful for other dimensions as well, such as understanding the role of religious orders as "departments" of the Catholic Church or missionary "strategies" in religious markets outside the US (see, e.g., the recent work on contemporary Pentecostal churches as multinationals in Hanson and Xiang (2013)). Other areas of economics where religion may 
prove influential include health, gender norms, and family economics. Public economics is another field that could benefit from studies in religion and history. Religious institutions in numerous religions have provided social safety nets. Explorations into what this meant for economic activity and how it crowded out (or in) public and other private investments seem an interesting direction for future research.

Maybe the most challenging theme for future research on religion in economic history would be to dig deeper into the link between economics and religiosity rather than religious affiliationwhat people think and feel and which specific beliefs they do and do not adhere to. Measuring religiosity and beliefs is demanding in contemporary work, and it is even harder in the historical context where the option of fielding a survey is no longer viable. While the work surveyed here has clearly shown that religion has played an important role in economic history, there remains ample room for advancements in our understanding of how religious thoughts and activities changed people's lives over the course of history. 


\section{References}

Abramitzky, Ran. 2015. “Economics and the Modern Economic Historian.” Journal of Economic History 75(4): 1240-1251.

Abramitzky, Ran. 2018. The Mystery of the Kibbutz: Egalitarian Principles in a Capitalist World. Princeton and Oxford: Princeton University Press.

Abramitzky, Ran, and Hanna Halaburda. 2020. "Were Jews in Interwar Poland More Educated?” Journal of Demographic Economics, forthcoming.

Acemoglu, Daron, Tarek A. Hassan, and James A. Robinson. 2011. "Social Structure and Development: A Legacy of the Holocaust in Russia.” Quarterly Journal of Economics 126(2): 895-946.

Ager, Philipp, and Antonio Ciccone. 2018. "Agricultural Risk and the Spread of Religious Communities.” Journal of the European Economic Association 16(4): 1021-1068.

Akçomak, İ Semih, Dinand Webbink, Bas ter Weel. 2016. "Why Did the Netherlands Develop So Early? The Legacy of the Brethren of the Common Life.” Economic Journal 126(593): 821860.

Akerlof, George. 1976. “The Economics of Caste and of the Rat Race and Other Woeful Tales.” Quarterly Journal of Economics 90(4): 599-617.

Alesina, Alberto, and Paola Giuliano. 2015. “Culture and Institutions.” Journal of Economic Literature 53(4): 898-944.

Andersen, Thomas Barnebeck, Jeanet Bentzen, Carl-Johan Dalgaard, and Paul Sharp. 2017. "Prereformation Roots of the Protestant Ethic.” Economic Journal 127(604): 1756-1793.

Anderson, Robert Warren, Noel D. Johnson, and Mark Koyama. 2017. "Jewish Persecutions and Weather Shocks: 1100-1800.” Economic Journal 127(602): 924-958.

Artunç, Cihan. 2015. "The Price of Legal Institutions: The Beratl1 Merchants in the EighteenthCentury Ottoman Empire.” Journal of Economic History 75(3): 720-748.

Auriol, Emmanuelle, and Jean-Phillippe Platteau. 2017. "Religious Co-option Under Autocracy: A Theory Inspired by History.” Journal of Development Economics 127: 395-412.

Bai, Ying, and James Kai-sing Kung. 2015. "Diffusing Knowledge while Spreading God's Message: Protestantism and Economic Prosperity in China, 1840-1920.” Journal of the European Economic Association 13(4): 669-698.

Baron, Salo W., and Arcadius Kahan. 1975. Economic History of the Jews. New York: Schocken Books. 
Barro, Robert J., and Rachel M. McCleary. 2003. "Religion and Economic Growth across Countries.” American Sociological Review 68(5): 760-781.

Barro, Robert J., and Rachel M. McCleary. 2005. “Which Countries Have State Religions?” Quarterly Journal of Economics 120(4): 1331-1370.

Barro, Robert J., and Rachel M. McCleary. 2016. “Saints Marching In, 1590-2012.” Economica 83(331): 385-415.

Basten, Christoph, and Frank Betz. 2013. "Beyond Work Ethic: Religion, Individual, and Political Preferences.” American Economic Journal: Economic Policy 5(3): 67-91.

Beach, Harlan P. 1903. A Geography and Atlas of Protestant Missions: Their Environment, Forces, Distribution, Methods, Problems, Results and Prospects at the Opening of the Twentieth Century, Vol. 2, New York: Student Volunteer Movement for Foreign Missions.

Beatton, Tony, Ahmed Skali, and Benno Torgler. 2019. "Protestantism and Effort Expenditure on the Battlefield: Soldier-Level Evidence from World War II.” Working Paper.

Becker, Sascha O., and Francesco Cinnirella. 2020. "Prussia Disaggregated: The Demography of its Universe of Localities in 1871.” Journal of Demographic Economics, forthcoming.

Becker, Sascha O., Francesco Cinnirella, and Ludger Woessmann. 2010. “The Trade-Off between Fertility and Education: Evidence from before the Demographic Transition.” Journal of Economic Growth 15(3): 177-204.

Becker, Sascha O., Erik Hornung, and Ludger Woessmann. 2011. "Education and Catch-up in the Industrial Revolution.” American Economic Journal: Macroeconomics 3(3): 92-126.

Becker, Sascha O., Yuan Hsiao, Steven Pfaff, and Jared Rubin. 2020. “Multiplex Network Ties and the Spatial Diffusion of Radical Innovations: Martin Luther's Leadership in the Early Reformation.” Working Paper

Becker, Sascha O., Volker Lindenthal, Sharun Mukand, and Fabian Waldinger. 2020. "Persecution and Escape: The Fate of Skilled Jews in Nazi Germany.” Mimeograph.

Becker, Sascha O., Markus Nagler, and Ludger Woessmann. 2017. "Education and Religious Participation: City-Level Evidence from Germany’s Secularization Period 1890-1930.” Journal of Economic Growth 22(3): 273-311.

Becker, Sascha O., and Luigi Pascali. 2019. "Religion, Division of Labor and Conflict: AntiSemitism in German Regions over 600 Years.” American Economic Review 109(5): 17641804.

Becker, Sascha O., Steven Pfaff, and Jared Rubin. 2016. "Causes and Consequences of the Protestant Reformation.” Explorations in Economic History 62: 1-25. 
Becker, Sascha O., Francisco J. Pino, and Jordi Vidal-Robert. 2019. “Economic Effects of Catholic Censorship during the Counter-Reformation.” Working Paper.

Becker, Sascha O., and Ludger Woessmann. 2008. "Luther and the Girls: Religious Denomination and the Female Education Gap in $19^{\text {th }}$ Century Prussia." Scandinavian Journal of Economics 110(4): 777-805.

Becker, Sascha O., and Ludger Woessmann. 2009. "Was Weber Wrong? A Human Capital Theory of Protestant Economic History.” Quarterly Journal of Economics 124(2): 531-596.

Becker, Sascha O., and Ludger Woessmann. 2010. "The Effect of Protestantism on Education before the Industrialization: Evidence from 1816 Prussia.” Economics Letters 107(2): 224228.

Becker, Sascha O., and Ludger Woessmann. 2013. "Not the Opium of the People: Income and Secularization in a Panel of Prussian Countries.” American Economic Review 103 (3): 539544.

Becker, Sascha O., and Ludger Woessmann. 2018. "Social Cohesion, Religious Beliefs, and the Effect of Protestantism on Suicide.” Review of Economics and Statistics 100(3): 377-391.

Belloc, Marianna, Francesco Drago, and Roberto Galbiati. 2016. “Earthquakes, Religion, and Transition to Self-Government in Italian Cities.” Quarterly Journal of Economics 131(4): 1875-1926.

Bentzen, Jeanet. 2019. "Acts of God? Religiosity and Natural Disasters Across Subnational World Districts.” Economic Journal 129(622): 2295-2321.

Berman, Eli. 2000. Sect, Subsidy, and Sacrifice: An Economist's View of Ultra-Orthodox Jews. Quarterly Journal of Economics 115(3): 905-953.

Blaydes, Lisa, and Eric Chaney. 2013. “The Feudal Revolution and Europe's Rise: Political Divergence of the Christian West and the Muslim World before 1500 CE.” American Political Science Review 107(1): 16-34.

Blaydes, Lisa, Justin Grimmer, and Alison McQueen. 2018. "Mirrors for Princes and Sultans: Advice on the Art of Governance in the Medieval Christian and Islamic Worlds.” Journal of Politics 80(4): 1150-1167.

Blaydes, Lisa, and Christopher Paik. 2016. “The Impact of Holy Land Crusades on State Formation: War Mobilization, Trade Integration, and Political Development in Medieval Europe.” International Organization 70(3): 551-586.

Blum, Matthias, and Claudia Rei. 2018. "Escaping Europe: Health and Human Capital of Holocaust Refugees.” European Review of Economic History 22(1): 1-27. 
Blum, Matthias, and Matthias Strebel. 2016. "Max Weber and the First World War: Protestant and Catholic Living Standards in Germany, 1915-1919.” Journal of Institutional Economics 12(3): 699-719.

Boerner, Lars, Jared Rubin, and Battista Severgnini. 2019. “A Time to Print, a Time to Reform.” Working Paper.

Boppart, Timo, Josef Falkinger, and Volker Grossmann. 2014. "Protestantism and Education: Reading (the Bible) and other Skills. Economic Inquiry 52(2): 874-895.

Boppart, Timo, Josef Falkinger, Volker Grossmann, Ulrich Woitek, and Gabriela Wüthrich. 2013. "Under Which Conditions Does Religion Affect Educational Outcomes?" Explorations in Economic History 50(2): 242-266.

Botticini, Maristella, and Zvi Eckstein. 2005. "Jewish Occupational Selection: Education, Restrictions, or Minorities?” Journal of Economic History 65(4): 922-948.

Botticini, Maristella, and Zvi Eckstein. 2007. "From Farmers to Merchants, Conversions and Diaspora: Human Capital and Jewish History.” Journal of the European Economic Association 5(5): 885-926.

Botticini, Maristella, and Zvi Eckstein. 2012. The Chosen Few: How Education Shaped Jewish History, 70-1492. Princeton: Princeton University Press.

Botticini, Maristella, Zvi Eckstein, and Anat Vaturi. 2019. "Child Care and Human Development: Insights from Jewish History in Central and Eastern Europe.” Economic Journal 129(10): 2637-2690.

Braun, Robert. 2016. "Religious Minorities and Resistance to Genocide: The Collective Rescue of Jews in the Netherlands during the Holocaust.” American Political Science Review 110(1): 127-147.

Buggle, Johannes, Thierry Mayer, Seyhun Orcan Sakalli, and Mathias Thoenig. 2020. “The Refugee's Dilemma: Evidence from Jewish Migration out of Nazi Germany.” Cahiers de Recherches Economiques du Département d'économie 20.01, Université de Lausanne, Faculté des HEC, Département d'économie.

Buringh, Eltjo, Bruce M. S. Campbell, Auke Rijpma, and Jan Luiten van Zanden. 2020. "Church Building and the Economy During Europe's 'Age of the Cathedrals', 700-1500 CE.” Explorations in Economic History 76: 101316.

Cagé, Julia, and Valeria Rueda. 2016. “The Long-Term Effects of the Printing Press in subSaharan Africa.” American Economic Journal: Applied Economics 8(3): 69-99.

Cagé, Julia, and Valeria Rueda. 2020. "Sex and the Mission: The Conflicting Effects of Early Christian Investments on Sub-Saharan Africa's HIV Epidemic.” Journal of Demographic Economics, forthcoming. 
Calvi, Rossella and Federico G. Mantovanelli. 2018. "Long-term Effects of Access to Health Care: Medical Missions in Colonial India,” Journal of Development Economics 135: 285-303.

Calvi, Rossella, Federico G. Mantovanelli, and Lauren Hoehn-Velasco 2019. "The Protestant Legacy: Missions and Human Capital in India.” Working Paper.

Cantoni, Davide. 2012. “Adopting a New Religion: The Case of Protestantism in $16^{\text {th }}$ Century Germany.” Economic Journal 122(560): 502-531.

Cantoni, Davide. 2015. "The Economic Effects of the Protestant Reformation: Testing the Weber Hypothesis in the German Lands.” Journal of the European Economic Association 13(4): 561598.

Cantoni, Davide, Jeremiah Dittmar, and Noam Yuchtman. 2018. "Religious Competition and Reallocation: The Political Economy of Secularization in the Protestant Reformation." Quarterly Journal of Economics 133(4): 2037-2096.

Cantoni, Davide, and Noam Yuchtman. 2020. "The Analysis of Natural Experiments in Historical Economics.” Chapter prepared for this Handbook.

Carvalho, Jean Paul, Sriya Iyer, and Jared Rubin (eds.). 2019. Advances in the Economics of Religion. New York: Palgrave Macmillan.

Carvalho, Jean Paul and Mark Koyama. 2016. "Jewish Emancipation and Schism: Economic Development and Religious Change.” Journal of Comparative Economics 44(3): 562-584.

Carvalho, Jean Paul, Mark Koyama, and Michael Sacks. 2017. "Education, Identity and Community: Lessons from Jewish Emancipation.” Public Choice 171(1): 119-143.

Castelló-Climent, Amparo, Latika Chaudhary, and Abhiroop Mukhopadhyay. 2018. "Higher Education and Prosperity: From Catholic Missionaries to Luminosity in India.” Economic Journal 128(616): 3039-3075.

Chaney, Eric. 2013. "Revolt on the Nile: Economic Shocks, Religion, and Political Power." Econometrica 81(5): 2033-2053.

Chaney, Eric. 2016. “Religion and the Rise and Fall of Islamic Science.” Working Paper.

Chaney, Eric. 2019. "Religion and Political Structure in Historical Perspective.” Working Paper.

Chaney, Eric, and Richard Hornbeck. 2016. "Economic Dynamics in the Malthusian Era: Evidence from the 1609 Spanish Expulsion of the Moriscos.” Economic Journal 126(594): 1404-1440.

Chaudhary, Latika, and Jared Rubin. 2011. "Reading, Writing, and Religion: Institutions and Human Capital Formation.” Journal of Comparative Economics 39(1): 17-33. 
Chaudhary, Latika, and Jared Rubin. 2016. "Religious Identity and the Provision of Public Goods: Evidence from the Indian Princely States.” Journal of Comparative Economics 44(3): 461483.

Coşgel, Metin M., Thomas J. Miceli, and Rasha Ahmed. 2009. "Law, State Power, and Taxation in Islamic History.” Journal of Economic Behavior and Organization 71(3): 704-717.

Coşgel, Metin M., Thomas J. Miceli, and Jared Rubin. 2012. "The Political Economy of Mass Printing: Legitimacy, Revolt, and Technology Change in the Ottoman Empire.” Journal of Comparative Economics 40(3): 357-371.

Curuk, Malik, and Sjak Smulders. 2019. "Malthus Meets Luther: The Economics behind the German Reformation.” Mimeograph.

D’Acunto, Francesco, Marcel Prokopczuk, and Michael Weber. 2019. "Historical Antisemitism, Ethnic Specialization, and Financial Development.” Review of Economic Studies 86(3): 11701206.

Dittmar, Jeremiah, and Ralf Meisenzahl. 2020. "Public Goods Institutions, Human Capital, and Growth: Evidence from German History.” Review of Economic Studies 87(2): 959-996.

Dittmar, Jeremiah, and Skipper Seabold. 2020. "New Media and Competition: Printing and Europe’s Transformation after Gutenberg.” Journal of Political Economy, forthcoming.

Doyle, Shane, Felix Meier zu Selhausen and Jacob Weisdorf. 2020. "The Blessings of Medicine? Patient Characteristics and Heath Outcomes in a Ugandan Mission Hospital, 1908-1970.” Social History of Medicine, forthcoming.

Durkheim, Émile (1897). Le suicide: étude de sociologie. Paris: Félix Alcan. [English translation: Suicide: A Study in Sociology, translated by John A. Spaulding and George Simpson, 1951, Glencoe: The Free Press.]

Durlauf, Steven N., Andros Kourtellos, and Chih Ming Tan. 2012. "Is God in the Details? A Reexamination of the Role of Religion in Economic Growth.” Journal of Applied Econometrics 27(7): 1059-1075.

Ekelund, Robert B. Jr., Robert F. Hébert, and Robert D. Tollison. 2002. “An Economic Analysis of the Protestant Reformation.” Journal of Political Economy 110(3): 646-671.

Ekelund, Robert B. Jr., Robert F. Hébert, and Robert D. Tollison. 2004. "The Economics of the Counter-Reformation: Incumbent-firm Reaction to Market Entry.” Economic Inquiry 42(4): 690-705.

Ekelund, Robert B., Robert D. Tollison, Gary M. Anderson, Robert F. Hébert, and Audrey B. Davidson. 1996. Sacred Trust: The Medieval Church as an Economic Firm. Oxford: Oxford University Press. 
Esteves, Rui, and Gabriel Geisler Mesevage. 2019. "Social Networks in Economic History: Opportunities and Challenges. Explorations in Economic History 74: 101299.

Finke, Roger and Rodney Stark. 2005. The Churching of America, 1776-2005: Winners and Losers in our Religious Economy, Second Edition. New Brunswick, NJ: Rutgers University Press.

Finkel, Evgeny. 2015. "The Phoenix Effect of State Repression: Jewish Resistance during the Holocaust.” American Political Science Review 109(2): 339-353.

Finley, Teresa, Raphaël Franck, and Noel D. Johnson. 2019. “The Effects of Land Redistribution: Evidence from the French Revolution.” Working Paper.

Finley, Teresa, and Mark Koyama. 2018. "Plague, Politics, and Pogroms: The Black Death, the Rule of Law, and the Persecution of Jews in the Holy Roman Empire." Journal of Law and Economics 61(2): 253-277.

Franck, Raphaël, and Laurence R. Iannaccone. 2014. "Religious Decline in the 20th Century West: Testing Alternative Explanations.” Public Choice 159(3-4): 385-414.

Freud, Sigmund. 1927. The Future of an Illusion. Edited by James Strachey (1961). New York: W. W. Norton.

Gallego, Francisco A., and Robert Woodberry. 2010. "Christian Missionaries and Education in Former African Colonies: How Competition Mattered.” Journal of African Economics 19(3): 294-329.

Galor, Oded. 2011. Unified Growth Theory. Princeton: Princeton University Press.

Gentzkow, Matthew, Bryan Kelly, and Matt Taddy. 2019. "Text as Data.” Journal of Economic Literature 57(3): 535-574.

Goody, Jack. 1983. The Development of the Family and Marriage in Europe. Cambridge: Cambridge University Press.

Greif, Avner. 1994. "Cultural Beliefs and the Organization of Society: A Historical and Theoretical Reflection on Collectivist and Individualist Societies." Journal of Political Economy 102(5): 912-950.

Greif, Avner. 2006a. "Family Structures, Institutions, and Growth.” American Economic Review 96(2): 308-312.

Greif, Avner. 2006b. Institutions and the Path to the Modern Economy: Lessons from Medieval Trade. New York: Cambridge University Press.

Greif, Avner, and Guido Tabellini. 2017. "The Clan and the Corporation: Sustaining Cooperation in China and Europe.” Journal of Comparative Economics 45(1): 1-35. 
Grosfeld, Irena, Alexander Rodnyansky, and Ekaterina Zhuravskaya. 2013. "Persistent Antimarket Culture: A Legacy of the Pale of Settlement after the Holocaust.” American Economic Journal: Economic Policy 5(3): 189-226.

Grosfeld, Irena, Seyhun Orcan Sakalli, and Ekaterina Zhuravskaya. 2020. "Middleman Minorities and Ethnic Conflict: Anti-Jewish Pogroms in the Russian Empire." Review of Economic Studies 87(1): 289-342.

Grosjean, Pauline. 2011. "The Institutional Legacy of the Ottoman Empire: Islamic Rule and Financial Development in South Eastern Europe.” Journal of Comparative Economics 39(1): $1-16$.

Guiso, Luigi, Paola Sapienza, and Luigi Zingales. 2006. "Does Culture Affect Economic Outcomes?” Journal of Economic Perspectives 20(2): 23-48.

Hanson, Gordon H., and Chong Yiang. 2013. "Exporting Christianity: Governance and Doctrine in the Globalization of US Denominations. Journal of International Economics 91(2): 301320.

Hanushek, Eric A., and Ludger Woessmann. 2015. The Knowledge Capital of Nations: Education and the Economics of Growth. Cambridge, MA: MIT Press.

Heldring, Leander, James A. Robinson, and Sebastian Vollmer. 2017. "The Long-Run Impact of the Dissolution of the English Monasteries.” Working Paper.

Henrich, Joseph, Jean Ensminger, Richard McElreath, Abigail Barr, Clark Barrett, Alexander Bolyanatz, Juan Camilo Cardenas, et al. 2010. "Markets, Religion, Community Size, and the Evolution of Fairness and Punishment.” Science 327(5972): 1480-1484.

Hoffman, Mitchell. 2011. "Does Higher Income Make You More Altruistic? Evidence from the Holocaust.” Review of Economics and Statistics 93(3): 876-887.

Hornung, Erik. 2014. "Immigration and the Diffusion of Technology: The Huguenot Diaspora in Prussia.” American Economic Review 104(1): 84-122.

Hume, David. 1757. The Natural History of Religion. Edited by J.C.A. Gaskin (1993). Oxford: Oxford University Press.

Iannaccone, Laurence R. 1992. "Sacrifice and Stigma: Reducing Free-riding in Cults, Communes, and other Collectives.” Journal of Political Economy 100(2): 271-291.

Iannaccone, Laurence R. 1998. "Introduction to the Economics of Religion.” Journal of Economic Literature 36(3): 1465-1495.

Iyer, Sriya. 2016. “The New Economics of Religion.” Journal of Economic Literature 54(2): 395441. 
Iyigun, Murat. 2008. "Luther and Suleyman.” Quarterly Journal of Economics 123(4): 14651494.

Iyigun, Murat. 2013. "Lessons from the Ottoman Harem on Culture, Religion, and Wars." Economic Development and Cultural Change 61(4): 693-730.

Iyigun, Murat. 2015. War, Peace and Prosperity in the Name of God: The Ottoman Role in Europe's Socioeconomic Evolution. Chicago: University of Chicago Press.

Jedwab, Remi, Noel Johnson, and Mark Koyama. 2019. "Negative Shocks and Mass Persecutions: Evidence from the Black Death.” Journal of Economic Growth 24(4): 345-395.

Jedwab, Remi, Felix Meier zu Selhausen, and Alexander Moradi. 2019. "The Economics of Missionary Expansion: Evidence from Africa and Implications for Development.” AEHNWP-49.

Jha, Saumitra. 2013. "Trade, Institutions, and Ethnic Tolerance: Evidence from South Asia.” American Political Science Review 107(4): 806-832.

Jha, Saumitra. 2018. “Trading for Peace.” Economic Policy 33(95): 485-526.

Johnson, Noel D., and Mark Koyama. 2017. "Jewish Communities and City Growth in Preindustrial Europe” Journal of Development Economics 127: 339-354.

Johnson, Noel D., and Mark Koyama. 2019. Persecution and Toleration: The Long Road to Religious Freedom. Cambridge: Cambridge University Press.

Kim, Hyojoung, and Steven Pfaff. 2012. "Structure and Dynamics of Religious Insurgency: Students and the Spread of the Reformation.” American Sociological Review 77(2): 188-215.

Koyama, Mark. 2010. "Evading the Taint of Usury: The Usury Prohibition as a Barrier to Entry.” Explorations in Economic History 47(4): 420-442.

Kuran, Timur. 2001. "The Provision of Public Goods under Islamic Law: Origins, Impact, and Limitations of the Waqf System.” Law and Society Review 35(4): 841-897.

Kuran, Timur. 2004. "The Economic Ascent of the Middle East’s Religious Minorities: The Role of Islamic Legal Pluralism.” Journal of Legal Studies 33: 475-515.

Kuran, Timur. 2005. “The Absence of the Corporation in Islamic Law: Origins and Persistence.” American Journal of Comparative Law 53: 785-834.

Kuran, Timur (ed.). 2010-13. Mahkeme Kayıtları Işı̆̆ında 17. Yüzyıl İstanbul'unda SosyoEkonomik Yaşam / Social and Economic Life in Seventeenth-Century Istanbul: Glimpses from Court Records, 10 vols. Istanbul: İş Bank Cultural Publications.

Kuran, Timur. 2011. The Long Divergence: How Islamic Law Held Back the Middle East. Princeton: Princeton University Press. 
Kuran, Timur. 2018. "Islam and Economic Performance: Historical and Contemporary Links.” Journal of Economic Literature 56(4): 1292-1359.

Kuran, Timur, and Scott Lustig. 2012. "Judicial Biases in Ottoman Istanbul: Islamic Justice and Its Compatibility with Modern Economic Life.” Journal of Law and Economics 55: 631-666.

Kuran, Timur, and Jared Rubin. 2018. "The Financial Power of the Powerless: Socio-economic Status and Interest Rates under Partial Rule of Law.” Economic Journal 128(609): 758-796.

Kuru, Ahmet T. 2019. Islam, Authoritarianism, and Underdevelopment: A Global and Historical Comparison. New York: Cambridge University Press.

Kuznets, Simon. 1960. “Economic Structure and Life of the Jews.” In: Louis Finkelstein (ed.), The Jews: Their History, Culture, and Religion, Vol. 2. New York: Harper, pp. 1597-1666.

Lal, Deepak. 1988. The Hindu Equilibrium. Vol. I Cultural Stability and Economic Stagnation. India c. 1500 BC-AD 1980. Oxford: Clarendon Press.

Leeson, Peter T., and Jacob W. Russ. 2018. “Witch Trials.” Economic Journal 128(613): 20662105.

Lehrer, Evelyn. 2008. Religion, Economics, and Demography: The Effects of Religion on Education, Work, and the Family. London: Routledge.

Ma, Chicheng. 2020. "Knowledge Diffusion and Intellectual Change: When Chinese Literati Met European Jesuits.” Working Paper.

Marx, Karl. 1844. “Zur Kritik der Hegel’schen Rechtsphilosophie: Einleitung. ” In: Arnold Ruge and Karl Marx (eds.), Deutsch-Französische Jahrbücher. Paris: Bureau der Jahrbücher, pp. 71-85.

McCleary, Rachel M. (ed.). 2011. Oxford Handbook of the Economics of Religion. Oxford: Oxford University Press.

McCleary, Rachel M. 2013. "Protestantism and Human Capital in Guatemala and the Republic of Korea.” Asian Development Bank Economics, Working Paper Series No. 332.

McCleary, Rachel M., and Robert J. Barro. 2006a. "Religion and Political Economy in an International Panel.” Journal for the Scientific Study of Religion 45(2): 149-175.

McCleary, Rachel M., and Robert J. Barro. 2006b. “Religion and Economy.” Journal of Economic Perspectives 20(2): 49-72.

McCleary, Rachel M., and Robert J. Barro. 2019. The Wealth of Religions: The Political Economy of Believing and Belonging. Princeton: Princeton University Press. 
Meier zu Selhausen, Felix. 2019. "Missions, Education and Conversion in Colonial Africa." In: Gabriele Cappelli and David Mitch (eds.), Globalization and Mass Education. London: Palgrave Macmillan, Chapter 2.

Michalopoulos, Stelios, Alireza Naghavi, and Giovanni Prarolo. 2016. "Islam, Inequality, and PreIndustrial Comparative Development.” Journal of Development Economics 120: 86-98.

Michalopoulos, Stelios, Alireza Naghavi, and Giovanni Prarolo. 2018. "Trade and Geography in the Spread of Islam.” Economic Journal 128(616): 3210-3241.

Mitchener, Kris. 2015. "The 4D Future of Economic History: Digitally-driven Data Design.” Journal of Economic History 75(4): 1234-1239.

Moser, Petra, Alessandra Voena, and Fabian Waldinger. 2014. "German Jewish Émigrés and US Invention.” American Economic Review 104(10): 3222-3255.

Norenzayan, Ara. 2013. Big Gods: How Religion Transformed Cooperation and Conflict. Princeton: Princeton University Press.

Nunn, Nathan. 2010. "Religious Conversion in Colonial Africa." American Economic Review 100(2): 147-152.

Nunn, Nathan. 2014. "Gender and Missionary Influence in Colonial Africa.” In: Emmanuel Akyeampong, Robert H. Bates, Nathan Nunn, and James Robinson (eds.), Africa's Development in Historical Perspective. New York: Cambridge University Press, pp. 489-512.

Paldam, Ella, and Martin Paldam. 2017. "The Political Economy of Churches in Denmark, 13002015.” Public Choice 172(3-4): 443-463.

Pascali, Luigi. 2016. "Banks and Development: Jewish Communities in the Italian Renaissance and Current Economic Performance.” Review of Economics and Statistics 98(1): 140-158.

Platteau, Jean-Phillippe. 2017. Islam Instrumentalised: Religion and Politics in Historical Perspective. Cambridge: Cambridge University Press.

Richardson, Gary, 2005. "Craft Guilds and Christianity in Late-medieval England.” Rationality and Society 17(2): 139-189.

Roome, William R. M. 1925. Ethnographic Survey of Africa: Showing the Tribes and Languages; also the Stations of Missionary Societies. London: Edward Stanford.

Rubin, Jared. 2009. "Social Insurance, Commitment, and the Origin of Law: Interest Bans in Early Christianity.” Journal of Law \& Economics 52(4): 761-777.

Rubin, Jared. 2010. "Bills of Exchange, Interest Bans, and Impersonal Exchange in Islam and Christianity." Explorations in Economic History 47(2): 213-227. 
Rubin, Jared. 2011. "Institutions, the Rise of Commerce and the Persistence of Laws: Interest Restrictions in Islam and Christianity.” Economic Journal 121(557): 1310-1339.

Rubin, Jared. 2014. "Printing and Protestants: An Empirical Test of the Role of Printing in the Reformation.” Review of Economics and Statistics 96(2): 270-286.

Rubin, Jared. 2017. Rulers, Religion, and Riches: Why the West Got Rich and the Middle East Did Not. Cambridge: Cambridge University Press.

Saleh, Mohamed. 2015. “The Reluctant Transformation: State Industrialization, Religion, and Human Capital in Nineteenth-Century Egypt.” Journal of Economic History 75(1): 65-94.

Saleh, Mohamed. 2016. "Public Mass Modern Education, Religion, and Human Capital in Twentieth-Century Egypt.” Journal of Economic History 76(3): 697-735.

Saleh, Mohamed. 2018. “On the Road to Heaven: Taxation, Conversions, and the Coptic-Muslim Socioeconomic Gap in Medieval Egypt.” Journal of Economic History 78(2): 394-434.

Saleh, Mohamed, and Jean Tirole. 2019. “Taxing Identity: Theory and Evidence from Early Islam.” CEPR Discussion Paper 13705.

Schulz, Jonathan F. 2019. “Kin Networks and Institutional Development.” Working Paper.

Schulz, Jonathan F., Duman Bahrami-Rad, Jonathan P. Beauchamp, and Joseph Henrich. 2019. “The Church, Intensive Kinship, and Global Psychological Variation.” Science 366(6466): eaau5141.

Shariff, Azim F., Ara Norenzayan, and Joseph Henrich. 2010. "The Birth of High Gods: How the Cultural Evolution of Supernatural Policing Influenced the Emergence of Complex, Cooperative Human Societies, Paving the Way for Civilization.” In Mark Schaller, Ara Norenzayan, Steven J. Heine, Toshio Yamagishi, and Tatsuya Kameda (eds.), Evolution, Culture and the Human Mind. New York: Psychology Press, pp. 119-136.

Smith, Adam. 1776. An Inquiry into the Nature and Causes of the Wealth of Nations. Oxford: Clarendon Press [1979].

Spenkuch, Jörg L. 2017. "Religion and Work: Micro Evidence from Contemporary Germany.” Journal of Economic Behavior and Organization 135: 193-214.

Spenkuch, Jörg L., and Philipp Tillmann. 2018. "Elite Influence? Religion and the Electoral Success of the Nazis.” American Journal of Political Science 62(1): 19-36.

Spitzer, Yannay. 2019. “Pale in Comparison: Jews as a Rural Service Minority.” Working Paper.

Squicciarini, Mara. 2020. "Devotion and Development: Religiosity, Education, and Economic Progress in 19 th -Century France.” American Economic Review, forthcoming. 
Ticku, Rohit, Anand Shrivastava, and Sriya Iyer. 2020. "Economic Shocks and Temple Desecrations in Medieval India.” Working Paper.

Uribe-Castro, Mateo. 2019. "Expropriation of Church Wealth and Political Conflict in $19^{\text {th }}$ Century Colombia.” Explorations in Economic History 73: 101271.

Valencia Caicedo, Felipe. 2019a. "The Mission: Human Capital Transmission, Economic Persistence, and Culture in South America.” Quarterly Journal of Economics 134(1): 507556.

Valencia Caicedo, Felipe. 2019b. "Missionaries in Latin America and Asia: A First Global Mass Education Wave.” In: Gabriele Cappelli and David Mitch (eds.), Globalization and Mass Education. London: Palgrave Macmillan, Chapter 3.

Voigtländer, Nico, and Hans-Joachim Voth. 2012. "Persecution Perpetuated: The Medieval Origins of Anti-Semitic Violence in Nazi Germany.” Quarterly Journal of Economics 127(3): 1339-1392.

Voigtländer, Nico, and Hans-Joachim Voth. 2015. "Nazi Indoctrination and Anti-Semitic Beliefs in Germany." Proceedings of the National Academy of Sciences 112(26): 7931-7936.

Voth, Hans-Joachim. 2019. "Long-term Persistence: The Myth and the Mystery.” Chapter prepared for this Handbook.

Waldinger, Fabian. 2010. "Quality Matters: The Expulsion of Professors and the Consequences for PhD Student Outcomes in Nazi Germany.” Journal of Political Economy 118(4): 787-831.

Waldinger, Fabian. 2012. "Peer Effects in Science: Evidence from the Dismissal of Scientists in Nazi Germany.” Review of Economic Studies 79(2): 838-861.

Waldinger, Maria. 2017. “The Long-run Effects of Missionary Orders in Mexico.” Journal of Development Economics 127: 355-378.

Wantchekon, Leonard, Natalija Novta, and Marko Klašnja. 2015. "Education and Human Capital Externalities: Evidence from Colonial Benin.” Quarterly Journal of Economics 130(2): 703757.

Weber, Max. 1904/05. "Die protestantische Ethik und der „Geist“ des Kapitalismus.” Archiv für Sozialwissenschaft und Sozialpolitik 20: 1-54 and 21: 1-110. Reprinted in: Gesammelte Aufsätze zur Religionssoziologie, 1920: 17-206. [English translation: The Protestant Ethic and the Spirit of Capitalism, translated by Talcott Parsons, 1930/2001, London: Routledge Classics.]

West, Martin R., and Ludger Woessmann. 2010. “'Every Catholic Child in a Catholic School’: Historical Resistance to State Schooling, Contemporary Private Competition and Student Achievement across Countries.” Economic Journal 120(546): F229-F255. 
Wietzke, Frank-Borge. 2015. "Long-Term Consequences of Colonial Institutions and Human Capital Investments: Sub-National Evidence from Madagascar.” World Development 66: 293307.

Woodberry, Robert D. 2004. "The Shadow of Empire: Christian Missions, Colonial Policy, and Democracy in Postcolonial Societies." Ph.D. dissertation, University of North Carolina at Chapel Hill.

Woodberry, Robert D. 2011. "Religion and the Spread of Human Capital and Political Institutions: Christian Missions as a Quasi-natural Experiment.” In: Rachel McCleary (ed.), The Oxford Handbook of the Economics of Religion. Oxford: Oxford University Press, pp. 111-131.

Woodberry, Robert D. 2012. "The Missionary Roots of Liberal Democracy.” American Political Science Review 106(2): 244-274.

Xiong, Heyu, and Yiling Zhao. 2020. "Sectarian Competition and the Market Provision of Human Capital.” Working Paper.

Young, Cristobal. 2009a. "Religion and Economic Growth in Western Europe: 1500-2000." Stanford University, Mimeograph.

Young, Cristobal. 2009b. "Model Uncertainty in Sociological Research: An Application to Religion and Economic Growth.” American Sociological Review 74(3): 380-397. 
Table 1: Jewish Occupational Specialization, Human Capital, and Emancipation

\begin{tabular}{|c|c|c|c|}
\hline Study & Setting & Method & Summary \\
\hline \multicolumn{4}{|c|}{ Jewish occupational specialization and human capital } \\
\hline Bottini and Eckstein (2005, 2007, 2012) & $\begin{array}{l}\text { Near East and } \\
\text { Europe, } 70 \mathrm{CE}-1492\end{array}$ & $\begin{array}{l}\text { Empirical, } \\
\text { theory }\end{array}$ & $\begin{array}{l}\text { Jews highly educated as result of religious norms from first century CE; farmers } \\
\text { struggling with education norm converted, reinforcing norm of stayers }\end{array}$ \\
\hline Becker and Cinnirella (2020) & Prussia 1871 & Empirical & $\begin{array}{l}\text { Positive association between share of Jews and literacy in rural, but not in urban } \\
\text { areas }\end{array}$ \\
\hline Abramitzky and Halaburda (2020) & Interwar Poland & Empirical & $\begin{array}{l}\text { Jewish education advantage masks composition effect: Jews more likely to live in } \\
\text { towns; Jews more educated in countryside, but less educated in cities }\end{array}$ \\
\hline Botticini, Eckstein, and Vaturi (2019) & $\begin{array}{l}\text { Central and Eastern } \\
\text { Europe, } 1500-1930\end{array}$ & Empirical & $\begin{array}{l}\text { Lower child mortality rates and faster population growth as result of breastfeeding } \\
\text { norm }\end{array}$ \\
\hline Pascali (2016) & Italy, 1470-2003 & Empirical & $\begin{array}{l}\text { Cities with history of Jewish lending in Middle Ages and later lending through } \\
\text { Monti di Pietà supported by Catholic Church have better financial development }\end{array}$ \\
\hline \multicolumn{4}{|l|}{ Jewish emancipation } \\
\hline Carvalho and Koyama (2016) & Europe, $19^{\text {th }} \mathrm{c}$ & Theory & $\begin{array}{l}\text { Reform Judaism in more developed German Empire as optimal response to } \\
\text { increased economic opportunities; more traditional model in Eastern Europe }\end{array}$ \\
\hline Carvalho, Koyama, and Sacks (2017) & Europe, $19^{\text {th }} \mathrm{c}$ & Theory & Less education to preserve cultural identity among Orthodox Jews \\
\hline Johnson and Koyama (2017) & Europe, $1400-1850$ & Empirical & Cities with Jewish communities grew faster; emancipation as key mechanism \\
\hline
\end{tabular}


Table 2: Jewish Persecution

\begin{tabular}{|c|c|c|c|}
\hline Study & Setting & Method & Summary \\
\hline \multicolumn{4}{|l|}{ Persistence of anti-Semitism } \\
\hline Voigtländer and Voth (2012) & $\begin{array}{l}\text { Germany, 1348- } \\
\text { WWII }\end{array}$ & Empirical & $\begin{array}{l}\text { German cities that experienced anti-Jewish ('Black Death') pogroms in } 1348 \text { also } \\
\text { showed higher levels of anti-Semitism in interwar period }\end{array}$ \\
\hline $\begin{array}{l}\text { D’Acunto, Prokopczuk, and Weber } \\
\text { (2019) }\end{array}$ & $\begin{array}{l}\text { Germany, } 1348- \\
\text { today }\end{array}$ & Empirical & Places with historic anti-Semitism show lower modern-day financial development \\
\hline $\begin{array}{l}\text { Grosfeld, Rodnyansky, and } \\
\text { Zhuravskaya (2013) }\end{array}$ & $\begin{array}{l}\text { Russian Empire, } 19^{\text {th }} \\
\text { c - today }\end{array}$ & Empirical & $\begin{array}{l}\text { Current-day residents of former Pale of Settlement (where Jews were confined to } \\
\text { live within Russian Empire) have lower support for market }\end{array}$ \\
\hline \multicolumn{4}{|l|}{ Roots of anti-Semitism } \\
\hline $\begin{array}{l}\text { Anderson, Johnson, and Koyama } \\
\text { (2017) }\end{array}$ & Europe, 1100-1800 & Empirical & $\begin{array}{l}\text { More persecutions following colder growing seasons; effect strongest in weak } \\
\text { states and those with poor quality soil }\end{array}$ \\
\hline Johnson and Koyama (2019) & $\begin{array}{l}\text { Medieval and early } \\
\text { modern Europe }\end{array}$ & $\begin{array}{l}\text { Empirical, } \\
\text { narrative }\end{array}$ & $\begin{array}{l}\text { Persecution of religious minorities more likely to happen when states have low } \\
\text { capacity and rely on religious legitimacy; application to Jewish persecutions }\end{array}$ \\
\hline Finley and Koyama (2018) & $\begin{array}{l}\text { Holy Roman } \\
\text { Empire, } 1348 / 49\end{array}$ & Empirical & Black Death pogroms were affected by institutional determinants \\
\hline Jedwab, Johnson, and Koyama (2019) & Europe, 1100-1850 & Empirical & Black Death interacted with economic complementarity and substitutability \\
\hline $\begin{array}{l}\text { Grosfeld, Sakalli, and Zhuravskaya } \\
\text { (2020) }\end{array}$ & $\begin{array}{l}\text { Russian Empire, } \\
1800-1927\end{array}$ & Empirical & $\begin{array}{l}\text { When crop failures coincided with political turmoil, pogroms occurred in Pale of } \\
\text { Settlement in places where Jews dominated moneylending and trade in grain }\end{array}$ \\
\hline Becker and Pascali (2019) & $\begin{array}{l}\text { Germany, 1300- } \\
1900\end{array}$ & Empirical & $\begin{array}{l}\text { Protestant Reformation led to increased competition between Christian majority } \\
\text { and Jews who specialized in banking and led to increased anti-Semitism }\end{array}$ \\
\hline
\end{tabular}

(continued on next page) 
Table 2 (continued)

\begin{tabular}{|c|c|c|c|}
\hline Study & Setting & Method & Summary \\
\hline \multicolumn{4}{|l|}{ The Holocaust } \\
\hline Spenkuch and Tillmann (2018) & Germany, 1920s/30s & Empirical & Protestantism strongest predictor of Nazi vote shares \\
\hline $\begin{array}{l}\text { Buggle, Mayer, Sakalli, and Thoenig } \\
\text { (2020) }\end{array}$ & Germany, 1930s/40s & Empirical & $\begin{array}{l}\text { Emigration of Jews from Nazi Germany hampered by immigration restrictions; } \\
\text { network effects important in decision to emigrate }\end{array}$ \\
\hline $\begin{array}{l}\text { Becker, Lindenthal, Mukand, and } \\
\text { Waldinger (2020) }\end{array}$ & Germany, 1930s/40s & Empirical & $\begin{array}{l}\text { Emigration of Jewish academics exploits academic networks; early dismissal a } \\
\text { blessing in disguise }\end{array}$ \\
\hline Blum and Rei (2018) & Portugal, 1940s & Empirical & Persecuted Jews fleeing Europe for the US positively selected on education \\
\hline Hoffman (2011) & Europe, $1930 \mathrm{~s} / 40 \mathrm{~s}$ & Empirical & More rescuers of Jews in richer countries; rescuers richer individuals \\
\hline Braun (2016) & $\begin{array}{l}\text { Netherlands, } \\
\text { 1930s/40s }\end{array}$ & Empirical & $\begin{array}{l}\text { Minorities help minorities: Jews more likely to be rescued by respective Christian } \\
\text { minority in different parts of Netherlands }\end{array}$ \\
\hline Finkel (2015) & $\begin{array}{l}\text { Jewish ghettos, } \\
\text { 1930s/40s }\end{array}$ & $\begin{array}{l}\text { Analytic } \\
\text { narrative }\end{array}$ & Jewish resistance increases with previous experience of selective repression \\
\hline \multicolumn{4}{|l|}{ Consequences of the Holocaust } \\
\hline $\begin{array}{l}\text { Acemoglu, Hassan, and Robinson } \\
\text { (2011) }\end{array}$ & $\begin{array}{l}\text { Russia, WWII and } \\
\text { today }\end{array}$ & Empirical & $\begin{array}{l}\text { Cities with intense Holocaust have lower population today and more communist } \\
\text { votes since collapse of Soviet Union }\end{array}$ \\
\hline Voigtländer and Voth (2015) & $\begin{array}{l}\text { Germany, } 1930 \text { s/40s } \\
\text { and today }\end{array}$ & Empirical & $\begin{array}{l}\text { Germans who grew up under Nazi regime more anti-Semitic than those born } \\
\text { before or after that period }\end{array}$ \\
\hline Waldinger (2010) & $\begin{array}{l}\text { Germany, } 1933 \text { and } \\
\text { after WWII }\end{array}$ & Empirical & Negative effects of expulsion of Jewish math professors on PhD student outcomes \\
\hline Waldinger (2012) & $\begin{array}{l}\text { Germany, } 1933 \text { and } \\
\text { after WWII }\end{array}$ & Empirical & $\begin{array}{l}\text { No evidence of negative effects on productivity of colleagues after dismissal of } \\
\text { Jewish scientists }\end{array}$ \\
\hline Moser, Voena, and Waldinger (2014) & US, after 1933 & Empirical & $\begin{array}{l}\text { Patenting by US inventors increased in fields of émigré Jewish professors from } \\
\text { Nazi Germany }\end{array}$ \\
\hline
\end{tabular}




\section{Table 3: Catholicism}

\begin{tabular}{|c|c|c|c|}
\hline Study & Setting & Method & Summary \\
\hline \multicolumn{4}{|l|}{ Family structure and rise of communes } \\
\hline $\begin{array}{l}\text { Greif (2006a, 2006b); Greif and } \\
\text { Tabellini (2017) }\end{array}$ & Medieval Europe & Theory & $\begin{array}{l}\text { Church restrictions on cousin marriage contributed to weaker "clan" relations and } \\
\text { the rise of the corporate form }\end{array}$ \\
\hline $\begin{array}{l}\text { Schulz (2019); Schulz, Bahrami-Rad, } \\
\text { Beauchamp, and Henrich (2019) }\end{array}$ & Medieval Europe & Empirical & Exposure to Church predicts formation of communes \\
\hline Belloc, Drago, and Galbiati (2016) & 1000-1300, Italy & Empirical & Earthquakes gave local political authority more power and delayed communes \\
\hline \multicolumn{4}{|c|}{ State development, guilds, and human capital } \\
\hline Blaydes and Paik (2016) & Medieval Europe & Empirical & Crusades played a role in medieval state formation \\
\hline Richardson (2005) & Medieval Europe & Theory & Religion held guilds together by increasing cost of expulsion \\
\hline $\begin{array}{l}\text { Andersen, Bentzen, Dalgaard, and } \\
\text { Sharp (2017) }\end{array}$ & England, 1377-1801 & Empirical & Exposure to Cistercian monasteries increased city productivity growth \\
\hline $\begin{array}{l}\text { Akçomak, Webbink, and ter Weel } \\
\text { (2016) }\end{array}$ & $14^{\text {th }} \mathrm{c}$ Netherlands & Empirical & Brethren of the Common Life responsible for early Dutch capitalism \\
\hline Squicciarini (2020) & $19^{\text {th }}$ c France & Empirical & Negative effect of French Church on industrialization during second phase \\
\hline Finley, Franck, and Johnson (2019) & $19^{\text {th }}$ c France & Empirical & $\begin{array}{l}\text { Regions where Church land was redistributed during French Revolution had } \\
\text { greater subsequent productivity }\end{array}$ \\
\hline Uribe-Castro (2019) & $19^{\text {th }}$ C Colombia & Empirical & Regions where Church land was expropriated had less subsequent political conflict \\
\hline \multicolumn{4}{|l|}{ The Counter-Reformation } \\
\hline $\begin{array}{l}\text { Ekelund, Hébert, and Tollison (1996, } \\
\text { 2004) }\end{array}$ & $16^{\text {th }} \mathrm{c}$ Europe & Theory & Church as incumbent trying to fight off new entrants \\
\hline Becker, Pino, and Vidal-Robert (2019) & $16^{\text {th }}-18^{\text {th }}$ c Europe & Empirical & Cities defying index of prohibited books grew faster and attracted famous people \\
\hline \multicolumn{4}{|l|}{ Church doctrine } \\
\hline Barro and McCleary (2016) & 1590-present & Empirical & Beatification, canonization of saints respond to religious and political incentives \\
\hline Rubin (2009) & Late Roman Empire & Theory & Christian usury ban enacted to discourage moral hazard in late Roman Empire \\
\hline Koyama (2010) & Medieval Europe & Theory & Medieval usury ban allowed small number of merchants to make monopoly rents \\
\hline
\end{tabular}


Table 4: Socioeconomic Consequences of the Reformation

\begin{tabular}{|c|c|c|c|}
\hline Study & Setting & Method & Summary \\
\hline \multicolumn{4}{|c|}{ Protestantism, human capital, and socioeconomic outcomes } \\
\hline Becker and Woessmann (2009) & Prussia, late $19^{\text {th }} \mathrm{c}$ & Empirical & $\begin{array}{l}\text { Human capital theory of Protestant economic history: Protestantism increased } \\
\text { literacy and economic outcomes }\end{array}$ \\
\hline Becker and Woessmann (2010) & Prussia, 1816 & Empirical & Effect of Protestantism on education already before industrialization \\
\hline Becker and Woessmann (2008) & Prussia, $19^{\text {th }} c$ & Empirical & Protestantism decreased gender gap in education \\
\hline Boppart et al. (2013, 2014) & Switzerland, late $19^{\text {th }} \mathrm{c}$ & Empirical & Effect of Protestantism on educational spending and performance in Switzerland \\
\hline $\begin{array}{l}\text { Becker, Cinnirella, and } \\
\text { Woessmann (2010) }\end{array}$ & Prussia, 1849-1905 & Empirical & Protestantism-induced education reduced fertility \\
\hline $\begin{array}{l}\text { Becker, Hornung, and } \\
\text { Woessmann (2011) }\end{array}$ & Prussia, $19^{\text {th }} \mathrm{C}$ & Empirical & $\begin{array}{l}\text { Protestantism-induced education increased non-textile industrialization in both } \\
\text { phases of Industrial Revolution }\end{array}$ \\
\hline Hornung (2014) & Brandenburg, 1700, 1802 & Empirical & Long-run effect of Huguenot immigrants on productivity of textile manufactories \\
\hline \multicolumn{4}{|c|}{ Reformation, Protestant ethic, and socioeconomic outcomes } \\
\hline Cantoni (2015) & Germany, 1300-1900 & Empirical & No effect of Protestantism on German city growth \\
\hline Dittmar and Meisenzahl (2020) & Germany, 1520-1819 & Empirical & $\begin{array}{l}\text { Adoption of church ordinances after plagues increased upper-tail human capital } \\
\text { and city population growth }\end{array}$ \\
\hline Spenkuch (2017) & Germany, $17^{\text {th }} \mathrm{c}$, today & Empirical & Protestant areas in 1624 have longer working hours, but not hourly wages, today \\
\hline Basten and Betz (2013) & Switzerland, $16^{\text {th }}$ c, today & Empirical & $\begin{array}{l}\text { Protestantism reduced political preferences for leisure time, redistribution, and } \\
\text { government intervention }\end{array}$ \\
\hline Beatton, Skali and Torgler (2019) & Germany, WWII & Empirical & Protestant soldiers expend more effort than Catholic soldiers in WWII \\
\hline Blum and Strebel (2016) & Germany, WWI & Empirical & Height decrease of cohort born in WWI lower for Protestants than Catholics \\
\hline $\begin{array}{l}\text { Cantoni, Dittmar, and Yuchtman } \\
\text { (2018) }\end{array}$ & Germany, 1480-1600 & Empirical & $\begin{array}{l}\text { Reallocation of human and physical capital investment from religious to secular } \\
\text { purposes in immediate aftermath of Reformation }\end{array}$ \\
\hline $\begin{array}{l}\text { Heldring, Robinson, and Vollmer } \\
\text { (2017) }\end{array}$ & England, $16^{\text {th }}-18^{\text {th }} \mathrm{c}$ & Empirical & Dissolution of monasteries increased agricultural and industrial productivity \\
\hline \multicolumn{4}{|c|}{ Negative socioeconomic consequences of Reformation } \\
\hline Becker and Woessmann (2018) & Prussia, early and late $19^{\text {th }} \mathrm{c}$ & Empirical & Protestantism increased suicide; social cohesion as mechanism \\
\hline Leeson and Russ (2018) & Europe, $1500-1700$ & Empirical & Catholic-Protestant battles increased witch trial incidence \\
\hline
\end{tabular}


Table 5: Socioeconomic Causes of the Reformation, of its Spread, and of Protestant Religiosity

\begin{tabular}{|c|c|c|c|}
\hline Study & Setting & Method & Summary \\
\hline \multicolumn{4}{|c|}{ Causes of adoption and spread of Reformation } \\
\hline $\begin{array}{l}\text { Ekelund, Hébert, and Tollison } \\
\text { (2002) }\end{array}$ & Reformation & $\begin{array}{l}\text { Theory, } \\
\text { narrative }\end{array}$ & $\begin{array}{l}\text { Monopolistic practices of medieval Catholic Church encouraged Protestant entry in } \\
\text { entrepreneurial societies with declining feudalism and unstable wealth distribution }\end{array}$ \\
\hline Kim and Pfaff (2012) & Germany, 1517-1545 & Empirical & $\begin{array}{l}\text { Cities with students in Protestant rather than Catholic universities before } 1523 \text { more } \\
\text { likely to enact Reformation }\end{array}$ \\
\hline $\begin{array}{l}\text { Becker, Hsiao, Pfaff, and } \\
\text { Rubin (2020) }\end{array}$ & Germany before 1530 & Empirical & $\begin{array}{l}\text { Cities with personal ties (letters, visits, Wittenberg students) to Luther before } 1523 \\
\text { more likely to enact Reformation; interacts with spatial diffusion along trade routes }\end{array}$ \\
\hline Cantoni (2012) & Germany, 1600 & Empirical & $\begin{array}{l}\text { Distance to Wittenberg, ecclesiastical rule, and political and economic power } \\
\text { reduce Protestantism }\end{array}$ \\
\hline Curuk and Smulders (2019) & Germany, 1600 & Empirical & Agricultural potential and smaller population 1500 increase Protestantism \\
\hline Rubin (2014) & European cities, 1500-1600 & Empirical & Having printing press by 1500 increases Protestant adoption by 1600 \\
\hline $\begin{array}{l}\text { Boerner, Rubin, and Severgnini } \\
\text { (2018) }\end{array}$ & European cities, $1450-1600$ & Empirical & Indirect effect of mechanical clock on Reformation through printing press \\
\hline Dittmar and Seabold (2020) & Germany, 1454-1600 & Empirical & Printing competition increased Protestant book content and Reformation adoption \\
\hline Iyigun (2008) & Europe, 1521-1650 & Empirical & Ottoman incursions reduced Catholic-Protestant conflicts within Europe \\
\hline \multicolumn{4}{|c|}{ Causes of Protestant secularization } \\
\hline Becker and Woessmann (2013) & Prussia, 1886-1911 & Empirical & No effect of income on church attendance in panel models \\
\hline $\begin{array}{l}\text { Becker, Nagler, and } \\
\text { Woessmann (2017) }\end{array}$ & Germany, 1890-1930 & Empirical & Advanced-school expansion reduced church attendance in panel models \\
\hline
\end{tabular}




\section{Table 6: Missionaries}

\begin{tabular}{|c|c|c|c|}
\hline Study & Setting & Method & Summary \\
\hline \multicolumn{4}{|c|}{ Missionaries, human capital, and health: Africa } \\
\hline Gallego and Woodberry (2010) & Africa & Empirical & Regions where Protestant missionaries dominated have higher literacy; role of competition \\
\hline Nunn (2014) & Africa & Empirical & In areas with Protestant missionaries, education effect more pronounced for women \\
\hline $\begin{array}{l}\text { Wantchekon, Novta, and } \\
\text { Klašnja (2015) }\end{array}$ & Benin & Empirical & $\begin{array}{l}\text { Village-level externalities: descendants of the uneducated in villages with schools do better than } \\
\text { those in control villages }\end{array}$ \\
\hline $\begin{array}{l}\text { Doyle, Meier zu Selhausen, } \\
\text { and Weisdorf (2019) }\end{array}$ & Uganda & Empirical & Christian African converts adopted healthier sexual behavior already during colonial period \\
\hline Cagé and Rueda (2020) & Africa & Empirical & Christian missionaries influenced sexual beliefs and behaviors that affected risk of HIV contagion \\
\hline Wietzke (2015) & Madagascar & Empirical & Colonial institutions had stronger effect on local economic outcomes than missionary schools \\
\hline \multicolumn{4}{|c|}{ Missionaries, human capital, and health: Asia } \\
\hline Мa (2020) & China & Empirical & Jesuits missionaries stimulated Confucian literati to study science \\
\hline Bai and Kung (2015) & China & Empirical & Protestant missionaries associated with schools, hospitals, and better economic development \\
\hline $\begin{array}{l}\text { Calvi, Mantovanelli, and } \\
\text { Hoehn-Velasco (2019) }\end{array}$ & India & Empirical & Protestant missionaries associated with higher literacy \\
\hline Calvi and Mantovanelli (2018) & India & Empirical & Current health outcomes better the closer a village to historical Protestant medical missions \\
\hline $\begin{array}{l}\text { Castelló-Climent, Chaudhary, } \\
\text { and Mukhopadhyay (2018) }\end{array}$ & India & Empirical & Catholic missions associated with higher secondary school completion \\
\hline \multicolumn{4}{|c|}{ Missionaries, human capital, and health: Latin America } \\
\hline Waldinger (2017) & Mexico & Empirical & Areas with historical presence of Catholic mendicant orders have higher literacy and education today \\
\hline Valencia Caicedo (2019a) & S. America & Empirical & Jesuit missions in South America promoted education; effects persist 250 years later \\
\hline \multicolumn{4}{|c|}{ Missionaries and other outcomes } \\
\hline Nunn $(2010)$ & Africa & Empirical & Christian missionaries had lasting impact on religious beliefs \\
\hline Woodberry (2012) & Worldwide & Empirical & Protestant missionaries influenced rise and spread of stable democracy \\
\hline Cagé and Rueda (2016) & Africa & Empirical & $\begin{array}{l}\text { In regions close to Protestant missions, proximity to printing press associated with higher newspaper } \\
\text { readership, trust, education, and political participation }\end{array}$ \\
\hline \multicolumn{4}{|l|}{ Missionary expansion } \\
\hline Meier zu Selhausen (2019) & Africa & Empirical & Africanization of missions relevant to understand reach of initially European missionaries \\
\hline $\begin{array}{l}\text { Jedwab, Meier zu Selhausen, } \\
\text { and Moradi (2019) }\end{array}$ & Africa & Empirical & Smaller effect size of missionaries when considering local determinants of missionary expansion \\
\hline
\end{tabular}




\section{Table 7: Islam: Politics and Law}

\begin{tabular}{|c|c|c|c|}
\hline Study & Setting & Method & Summary \\
\hline \multicolumn{4}{|c|}{ Religious legitimacy and political economy } \\
\hline Rubin (2017) & Roman Empire-1600 & $\begin{array}{l}\text { Narrative, } \\
\text { theory }\end{array}$ & $\begin{array}{l}\text { Legitimating role of Muslim clerics meant that economic elite had little say at political } \\
\text { bargaining table, unlike in (post-Reformation) Europe }\end{array}$ \\
\hline $\begin{array}{l}\text { Coşgel, Miceli, and } \\
\text { Rubin (2012) }\end{array}$ & $\begin{array}{l}\text { Ottoman Empire, } 1485-18^{\text {th }} \\
\text { c }\end{array}$ & $\begin{array}{l}\text { Theory, } \\
\text { narrative }\end{array}$ & $\begin{array}{l}\text { Legitimating role of Ottoman clerics enabled prohibition of printing press for over two } \\
\text { centuries }\end{array}$ \\
\hline $\begin{array}{l}\text { Blaydes, Grimmer, and } \\
\text { McQueen (2018) }\end{array}$ & $\begin{array}{l}\text { Medieval Middle East and } \\
\text { Europe }\end{array}$ & $\begin{array}{l}\text { Empirical, } \\
\text { text } \\
\text { analysis }\end{array}$ & $\begin{array}{l}\text { Increase in religious appeals in advice given to Muslim rulers in political texts beginning } \\
\text { in } 12^{\text {th }}-14^{\text {th }} \text { centuries }\end{array}$ \\
\hline Chaney (2013) & Medieval Egypt & Empirical & Religious authority gained power and security with flooding or drought of Nile River \\
\hline $\begin{array}{l}\text { Ticku, Shrivastava, and } \\
\text { Iyer (2020) }\end{array}$ & Medieval India & Empirical & Muslim desecration of Hindu temples more likely following economic shocks \\
\hline $\begin{array}{l}\text { Blaydes and Chaney } \\
\text { (2013); Chaney (2019) }\end{array}$ & $\begin{array}{l}\text { Medieval Europe and } \\
\text { Middle East }\end{array}$ & Empirical & $\begin{array}{l}\text { Slave soldiers allowed Muslim rulers to not have to bargain with other elites; European } \\
\text { rulers constrained by feudal lords }\end{array}$ \\
\hline $\begin{array}{l}\text { Auriol and Platteau } \\
\text { (2017); Platteau (2017) }\end{array}$ & Early Islam to present & $\begin{array}{l}\text { Theory, } \\
\text { narrative }\end{array}$ & $\begin{array}{l}\text { Decentralized nature of Islam meant that rulers had to appease marginal cleric, leaving } \\
\text { many on outside, increasing instability }\end{array}$ \\
\hline 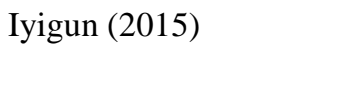 & Roman Empire to present & $\begin{array}{l}\text { Theory, } \\
\text { empirical }\end{array}$ & $\begin{array}{l}\text { Monotheism, “one true God” doctrine mean that inter-faith conflict is existential in } \\
\text { Western religions }\end{array}$ \\
\hline Iyigun $(2008,2013)$ & $\begin{array}{l}16^{\text {th }} \text { c Europe, Ottoman } \\
\text { Empire }\end{array}$ & Empirical & $\begin{array}{l}\text { Intra-European conflict less likely when Ottomans threatened Habsburgs; Ottoman threat } \\
\text { in Europe less likely when sultan's mother was Christian }\end{array}$ \\
\hline \multicolumn{4}{|l|}{ Islamic law } \\
\hline Kuran $(2005,2011)$ & $\begin{array}{l}\text { Medieval, early modern } \\
\text { Middle East }\end{array}$ & $\begin{array}{l}\text { Theory, } \\
\text { narrative }\end{array}$ & $\begin{array}{l}\text { Combination of Islamic inheritance and partnership law stifled emergence of large } \\
\text { partnerships and corporate form }\end{array}$ \\
\hline Kuran $(2001,2011)$ & $\begin{array}{l}\text { Medieval, early modern } \\
\text { Middle East }\end{array}$ & $\begin{array}{l}\text { Theory, } \\
\text { narrative }\end{array}$ & $\begin{array}{l}\text { Islamic waqf law used to evade inheritance law; inflexibility meant it could not turn into } \\
\text { more advanced, long-lived institution }\end{array}$ \\
\hline Kuran and Lustig (2012) & $16^{\text {th }}-19^{\text {th }}$ c Ottoman Empire & Empirical & Ottoman Islamic courts biased in favor of men, Muslims, and elites \\
\hline Kuran and Rubin (2018) & $16^{\text {th }}-19^{\text {th }}$ c Ottoman Empire & Empirical & Ottoman Islamic court bias meant that men, Muslims, and elites paid higher interest rates \\
\hline $\begin{array}{l}\text { Saleh (2018); Saleh and } \\
\text { Tirole (2019) }\end{array}$ & $8^{\text {th }} \mathrm{c}$ to early modern Egypt & $\begin{array}{l}\text { Empirical, } \\
\text { theory }\end{array}$ & $\begin{array}{l}\text { Islamic tax on religious minorities led to negative socioeconomic selection in converts; } \\
\text { incentivized rulers to over-tax }\end{array}$ \\
\hline
\end{tabular}


Table 8: Islam: Finance and Trade

\begin{tabular}{|c|c|c|c|}
\hline Study & Setting & Method & Summary \\
\hline \multicolumn{4}{|l|}{ Usury restrictions } \\
\hline Rubin $(2011,2017)$ & Medieval Middle East & $\begin{array}{l}\text { Theory; } \\
\text { narrative }\end{array}$ & $\begin{array}{l}\text { Middle Eastern reliance on religious legitimacy enabled equilibrium in which usury was } \\
\text { banned but permitted if ruse performed }\end{array}$ \\
\hline Rubin (2010) & Medieval Middle East & $\begin{array}{l}\text { Theory; } \\
\text { narrative }\end{array}$ & $\begin{array}{l}\text { Islamic usury ban prevented bills of exchange from being used as they were in Europe, } \\
\text { which stifled commercial development }\end{array}$ \\
\hline Grosjean (2011) & Southeastern Europe & Empirical & $\begin{array}{l}\text { Formerly Ottoman territories in Southeastern Europe have lower financial development } \\
\text { today, plausibly due to usury restrictions }\end{array}$ \\
\hline \multicolumn{4}{|l|}{ Trade and conflict } \\
\hline Jha (2013) & Medieval-20 $0^{\text {th }}$ c India & Empirical & Historical trade between Hindus and Muslims decreased $20^{\text {th }} \mathrm{c}$ inter-faith riots \\
\hline $\begin{array}{l}\text { Michalopoulos, Naghavi, and } \\
\text { Prarolo (2016, 2018) }\end{array}$ & $\begin{array}{l}7^{\text {th }} \text { and } 8^{\text {th }} \text { c Middle } \\
\text { East }\end{array}$ & $\begin{array}{l}\text { Theory; } \\
\text { empirical }\end{array}$ & $\begin{array}{l}\text { Role of trade in early spread of Islam; spread of early Islam and Islamic doctrine as means } \\
\text { of reducing conflict between groups with different factor endowments }\end{array}$ \\
\hline Chaney and Hornbeck (2016) & $17^{\text {th }}-19^{\text {th }}$ c Spain & Empirical & Very slow economic catch-up in Spain after 1609 expulsion of Moriscos \\
\hline \multicolumn{4}{|c|}{ Legal pluralism and merchants } \\
\hline Kuran (2004) & $\begin{array}{l}17^{\text {th }}-19^{\text {th }} \text { c Ottoman } \\
\text { Empire }\end{array}$ & Narrative & $\begin{array}{l}\text { Ottoman legal pluralism became disadvantage to Muslim merchants in } 18^{\text {th }} \text { and } 19^{\text {th }} \mathrm{c} \text { as } \\
\text { European commercial law became more complex }\end{array}$ \\
\hline Artunç (2015) & $19^{\text {th }} \mathrm{c}$ Ottoman Empire & Empirical & Ottoman exemption licenses to Europeans harmed native, Muslim merchants \\
\hline
\end{tabular}


Table 9: Islam: Human Capital

\begin{tabular}{|c|c|c|c|}
\hline Study & Setting & Method & Summary \\
\hline \multicolumn{4}{|c|}{ Scientific vs. religious human capital } \\
\hline Chaney (2016) & $\begin{array}{l}\text { Europe and Islamic } \\
\text { world, } 8^{\text {th }}-19^{\text {th }} \mathrm{C}\end{array}$ & Empirical & Rise of early Islamic science and decline, relative to religious texts, beginning in $11^{\text {th }}-12^{\text {th }} \mathrm{c}$ \\
\hline \multicolumn{4}{|c|}{ Human capital and industrialization } \\
\hline Saleh (2015) & $19^{\text {th }}$ c Egypt & Empirical & $\begin{array}{l}\text { Deskilling of Muslims and upskilling of Christians in first wave of industrialization; upskilling of } \\
\text { both in second wave }\end{array}$ \\
\hline Saleh (2016) & 1950s Egypt & Empirical & Reform of secular education improved outcomes for Muslims but not Christians \\
\hline \multicolumn{4}{|l|}{ Islam and literacy } \\
\hline $\begin{array}{l}\text { Chaudhary and Rubin } \\
(2011,2016)\end{array}$ & $19^{\text {th }}-20^{\text {th }} \mathrm{c}$ India & Empirical & $\begin{array}{l}\text { Parts of British India with more recent collapse of Muslim rule had lower Muslim literacy; Princely } \\
\text { States ruled by Muslims had lower Hindu literacy }\end{array}$ \\
\hline
\end{tabular}


Table 10: Cross-Country Studies of Religion in Economic History

\begin{tabular}{|c|c|c|c|}
\hline Study & Setting & Method & Summary \\
\hline \multicolumn{4}{|c|}{ Economic consequences of religion } \\
\hline Young (2009) & Europe, 1500-2000 & Empirical & Protestant countries’ GDP overtakes Catholic’s by 1700 \\
\hline West and Woessmann (2010) & OECD countries, 1900, 2003 & Empirical & $\begin{array}{l}\text { Catholicism in } 1900 \text { related to larger private-school shares and better student } \\
\text { achievement today }\end{array}$ \\
\hline \multicolumn{4}{|l|}{ Economic causes of religion } \\
\hline Franck and Iannaccone (2014) & Western countries, 1925-1990 & Empirical & Church attendance negatively associated with government spending on education \\
\hline Barro and McCleary (2005) & World, 1900, 1970, 2000 & Empirical & Persistent element in having a state religion \\
\hline Bentzen (2019) & World, 1981-2009 & Empirical & Religiosity increases in districts hit by earthquake \\
\hline
\end{tabular}

Bentzen (2019)

World, 1900, 1970, 2000

Empirical Religiosity increases in districts hit by earthquake 